Article

\title{
Geochemistry of Carboniferous-Permian Coal from the Wujiawan Mine, Datong Coalfield, Northern China: Modes of Occurrence, Origin of Valuable Trace Elements, and Potential Industrial Utilization
}

\author{
Jialiang Ma ${ }^{1,2} \oplus$, Lin Xiao ${ }^{1}$, Ke Zhang ${ }^{1}$, Yukun Jiao ${ }^{3}$, Zhenzhen Wang ${ }^{1}$, Jinxiao Li ${ }^{1}$, \\ Wenmu Guo ${ }^{1}$, Pengpeng Gao ${ }^{1}$, Shenjun Qin ${ }^{1}$ and Cunliang Zhao ${ }^{1, *}$ \\ 1 School of Earth Science and Engineering, Hebei University of Engineering, Handan 056038, China; \\ Ma@iau.uni-frankfurt.de (J.M.); xiaolin@hebeu.edu.cn (L.X.); Zhangke9801@163.com (K.Z.); \\ wzz90620512@163.com (Z.W.); lijinxiao1010@163.com (J.L.); gwm1992313@126.com (W.G.); \\ gaopengpeng5693@163.com (P.G.); qinsj528@hebeu.edu.cn (S.Q.) \\ 2 Institute for Atmospheric and Environmental Sciences, Faculty of Geoscience and Geography, \\ Goethe-University Frankfurt, 60438 Frankfurt am Main, Germany \\ 3 Hebei Provincal Coalfield Geology Bureau Geophysical Prospecting \& Survey Administration, \\ Xingtai 054000, China; jiaoyukun01@163.com \\ * Correspondence: zhaocunliang@hebeu.edu.cn
}

Received: 30 July 2020; Accepted: 29 August 2020; Published: 31 August 2020

\begin{abstract}
This paper provides new geochemical data focusing on valuable elements in the coal, parting, and floor samples in the No. 5 coal seam of the Taiyuan Formation from the Wujiawan mine, Datong coalfield, northern China. The minerals mainly consist of kaolinite, calcite, and pyrite, as well as trace amounts of quartz and illite. The No. 5 coal is enriched in Li, Ga, high field strength elements (HFSEs), and rare earth elements and yttrium (REY) when compared with world hard coals. Of particular interest is the high average concentration of $\mathrm{Li}(67.66 \mu \mathrm{g} / \mathrm{g})$, which is around seven times higher than the value for world hard coals. Lithium, Ga, and HFSEs have strong inorganic affinities, whereas REY have organic affinities. The main carrier of $\mathrm{Li}, \mathrm{Ga}$, and HFSEs is aluminosilicate minerals, while REY appear to occur with organophosphorus. These HFSEs are enriched, both in the parting and in the adjacent coal samples. This suggests that these elements are likely to leach out during the diagenetic process. The distribution patterns of REY, along with the ratio of $\mathrm{Al}_{2} \mathrm{O}_{3} / \mathrm{TiO}_{2}$ and the figure of $\mathrm{Zr} / \mathrm{TiO}_{2} \mathrm{vs} . \mathrm{Nb} / \mathrm{Y}$ are suggestive of their derivation from felsic parent material. In the northern and eastern part of the Datong coalfield, there are several regions where the Li content is higher than the mineable grade, in particular in the northern Datong coalfield where there is a mine with an $\mathrm{Li}$ content of $294.6 \mu \mathrm{g} / \mathrm{g}$. This is significantly higher than the mineable grade. Therefore, there is a potential for financially viable recovery of $\mathrm{Li}$ in these coals of the Datong coalfield.
\end{abstract}

Keywords: Datong coalfield; minerals; trace elements; felsic detrital; lithium

\section{Introduction}

According to the BP Statistical Review reported in 2019, global coal consumption increased by $1.4 \%$ in 2018 - the fastest increase since 2013 [1]. Coal consumption in China has grown, and will continue to increase, due to rapid economic development [2]. The presence of trace elements in coal and their modes of occurrence are influenced by synsedimentary factors and modification during the peat formation period (e.g., biochemical and detrital input), diagenetic stage (e.g., detrital input and seawater), as well as during epigenetic stages (e.g., geological factors and hydrothermal solutions) [3-6]. 
Numerous investigations on the elemental geochemistry in coals from north China have been carried out [7-19] and have revealed that various valuable elements can be found in high concentrations which gives them considerable economic significance [9,15,17,20-23]. Dai et al. [24] suggested that rare metals, such as REY, Cr, Ti, Li, Be, Au, Ag, Pt, Pd, etc., have high potential for industrial utilization in some Chinese coals. Meanwhile, Dai and Finkelman [25] reported that the extraction and utilization of some strategically important elements from coal could result in economic benefits.

Datong coalfield is one of the most important coal-producing areas in China, and studies have been carried out on the mineralogy and geochemistry from the Carboniferous and Permian coals in, and adjacent to, the Datong coalfield [7,9,10,16-18,20,26-28]. Findings from these studies have shown that the sediment source is dominated by both Cambrian-Ordovician strata as well as Archean metamorphic rocks [9,10,16-18,20,26-29]. Additionally, the low temperature hydrothermal solution activities in this area have significantly influenced the abundance and modes of occurrence of trace elements present in the coal. Studies have indicated that the coals from Yanzishan mine in the Datong coalfield are slightly enriched in Al, Li, Ga, and Ge [29]. Moreover, it has proven possible to recover $\mathrm{Al}$ and $\mathrm{Ge}$ as valuable byproducts from coal ash [30,31]. Other studies have indicated that Li has both organic and inorganic affinities in coals [9,32,33]. According to Dai et al. [10,12], clay minerals, such as boehmite and kaolinite are the main carriers of Ga. However, some researchers have suggested that Ga is partly organically bound in coals [20,34]. The mineralogical composition of the coal in the Yongdingzhuang mine from the Datong coalfield includes kaolinite and quartz, with trace amounts of anatase and pyrite [35].

The majority of previous studies concentrated only on coals from the northern-central region of the Datong coalfield [29,35,36]. In contrast, there is limited research available on the coals from the southern area, such as the Wujiawan mine, one of the biggest mines in the Datong coalfield. In 2020, the geochemistry of the No.6 coal from the Nanyangpo mine [37], located $5 \mathrm{~km}$ from the Wujiawan mine, was investigated with a focus on the origin of potentially harmful elements. In this study, we investigated the abundance and modes of occurrence of trace elements, with a particular focus on enriched valuable elements in the No. 5 coal from the Wujiawan mine. The results provide new data on the enrichment of valuable elements in the coal from the south Datong coalfield. Furthermore, the detailed discussion on the modes of occurrence and enrichment of valuable elements should provide support for policy makers in China with regard to the comprehensive utilization of coal from the Datong coalfield.

\section{Geological Background}

The Datong coalfield is located in the north of Shanxi Province in northern China (see Figure 1). The Yinshang Oldland is the main source region for the coalfields of Shanxi, and include the Ningwu and Datong coalfields [36,38]. The Datong coalfield is about $50 \mathrm{~km}$ in length (north to south) and $30 \mathrm{~km}$ in width (west to east), with a total area of around $1900 \mathrm{~km}^{2}$ [35]. The main coal-bearing strata in this basin are Carboniferous (C), Permian (P), and Jurassic (J). These coals in the Datong coalfield were deposited in a humid environment, and marine-terrigenous facies are the main deposits for $\mathrm{C}-\mathrm{P}$ coals, whereas the J coals were mostly formed in a terrestrial lake environment. The Datong coalfield is bordered by the Lvliang mountain syncline, Pingwang-Emaokou fault, and the Hongtao mountain syncline to the east, west, and north, respectively. Coal-bearing sequences are present mainly in the Benxi, Taiyuan, Shanxi, Shihezi, and Shiqianfeng formations in the coalfield. Two stages of magmatic intrusions are reported in the Datong coalfield [37,39]: a lamprophyre intrusion that occurred during the middle-late Triassic and a diabase intrusion during the late Early Cretaceous [37,40]. Four reverse faults, including the Emaokou Fault, the Meiyukou Fault, the Wangjiayuan Fault, and the Qingciyao Fault, occur from south to north [29,35-37]. These faults may have provided the channels for the hydrothermal fluid to flow into the coal-bearing sequence $[29,35,36]$.

The Wujiawan mine is situated in the southern region of the Datong coalfield with a total area of $9.37 \mathrm{~km}^{2}$ and has an annual output of more than 3 million tons of coal. Borehole data indicate that the 
strata of the study area are Cambrian, Ordovician, Carboniferous, Permian, Triassic, and Quaternary in ascending stratigraphic order. As Figure 2 shows, the Taiyuan Formation in the Carboniferous strata mainly consists of mudstone, siltstone, gritstone, pebbly-gritstone, carbonaceous-mudstone, and coal seams. The No.3, No. 5, No.8, and No.9 seams are the mineable coal seams of the Taiyuan Formation. The No. 5 coal seam has a total thickness of 33-138 m, with a floor mainly comprising of mudstone and a roof mainly of siltstone.

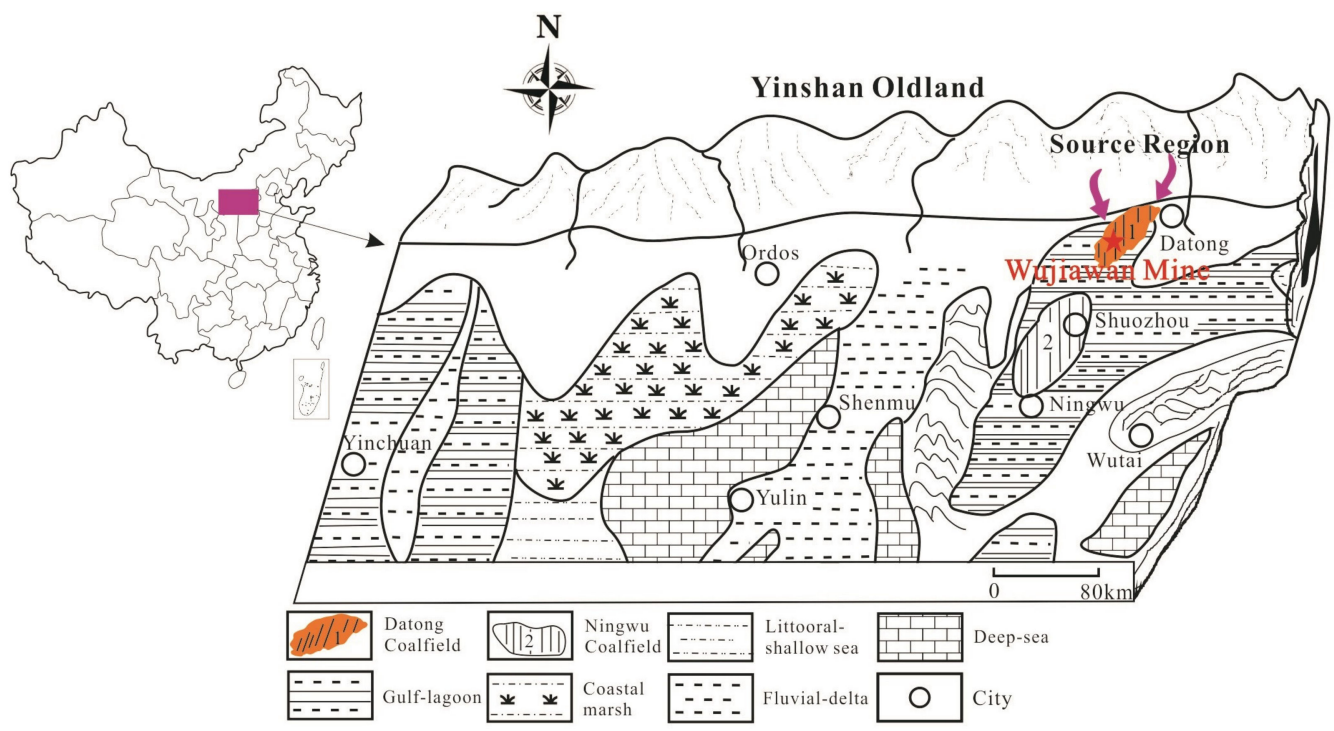

Figure 1. Paleogeographic setting and location of the Datong coalfield and Yinshan Oldland in the late Paleozoic. Modified from Sun et al. [9].

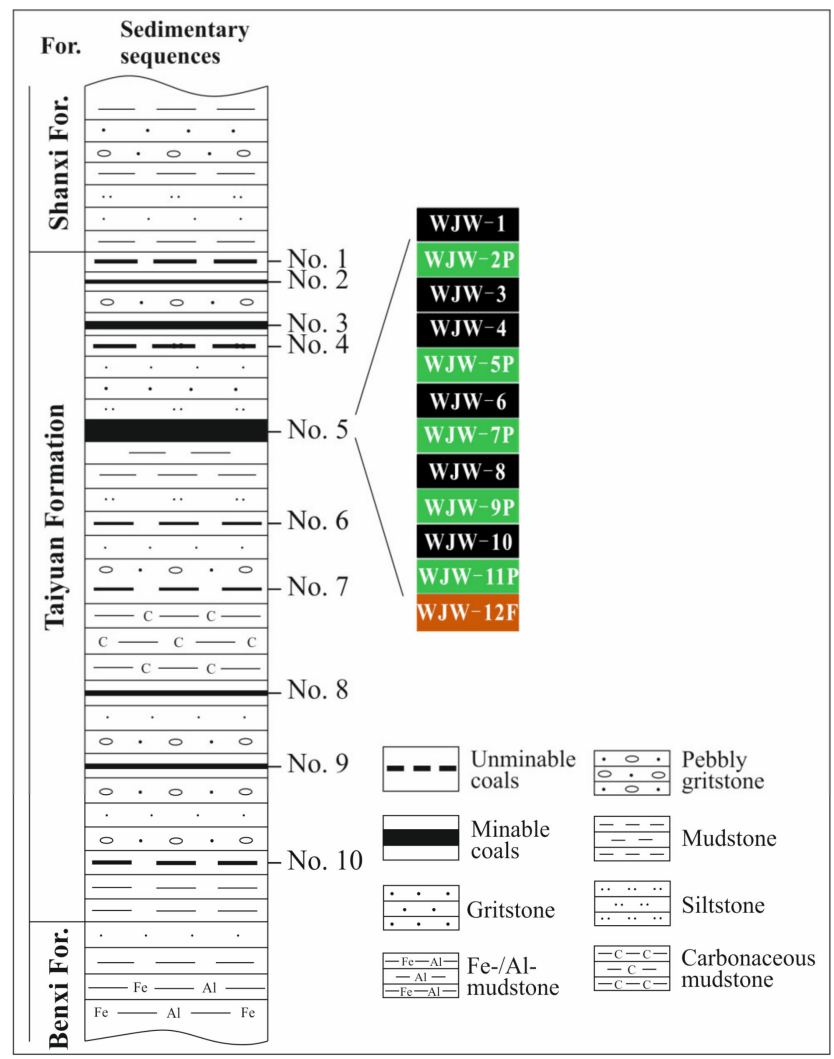

Figure 2. Stratigraphic column of the Wujiawan mine and lithological column of the sampling profile. For.: Formation, P: parting, F: floor. 


\section{Sampling and Methods}

In the present study, 6 coal bench samples (WJW-1, WJW-3, WJW-4, WJW-6, WJW-8, and WJW-10) and 6 partings (WJW-2, WJW-5, WJW-7, WJW-9, WJW-11, WJW12) were collected from top to bottom of No. 5 coal from the Wujiawan mine, according to the method of GB/T 482-2008 [41]. The No. 5 coal was represented by a total thickness of $2.7 \mathrm{~m}$, and every bench sample was cut with an area of $10 \mathrm{~cm} \times 10 \mathrm{~cm}$. All collected samples were split into two parts, one part for geochemical analyses and the other for future study.

Samples were crushed (by using a grinder whose material is hadifield steel for pulverization) to pass 200 mesh sieves for the proximate and related analyses. The analytical procedures of moisture, ash yield, volatile matter, and total sulfur were based on the ASTM Standards D3173-11 [42], D3174-11 [43], D3175-11 [44], and D3177-02 (2011) [45], respectively.

Samples were crushed into 80 mesh for optical microscopic and scanning electron microscopic analyses. According to ASTM D2798-05 [46], a Leica DM 2500 P (Leica, Solms, Germany) reflected light microscope coupled with a halogen lamp (Leica, Solms, Germany, oil lens 32/0.65, $548 \mathrm{~nm}$, $3 \times 3 \mu \mathrm{m}$, EMI9592 S-11; calibrated with a glass standard from Leitz, Ro $=0.89 \%$ ) was used to measure random vitrinite reflectance (Ro, ran). Mineralogical occurrence and distribution were analyzed under optical microscope (Leica DM 2500 P microscope by Leica Microsystems, Solms, Germany) and scanning electron microscope in conjunction with an energy dispersive $\mathrm{X}$-ray spectrometer (SEM-EDS, Hitachi SU8220, Tokyo, Japan). For SEM-EDS, each sample was platinum-plate coated (Although samples for SEM were platinum-plate coated, sometimes it could not be detected by EDS due to the very low concentration, especially in the organic area (on macerals)). All the samples were subjected to low temperature ashing (LTA), then the LTA samples, as well as powdered parting and floor samples, were detected under X-ray powder diffraction (XRD). The detailed analytical procedures of XRD are described in Ma et al. [37].

The 200-mesh samples were ashed at $815^{\circ} \mathrm{C}$ and the resultant ashes were then studied under X-ray fluorescence spectrometry (XRF) (ARL9800 XRF, Thermo Fisher Scientific, Waltham, MA, USA) to analyze the proportion of major elements. Meanwhile, the loss on ignition was also calculated at this temperature. The matrix correction and calibration of XRF is described by Ma et al. [37]. The contents of trace elements in the parting, floor, and coal samples were measured by Xseries II ICP-MS (Thermo Fisher Scientific, Waltham, MA, USA). Prior to the ICP-MS analysis, an amount of $40 \mathrm{mg}$ sample ( $<200 \mathrm{mesh})$ was weighed into Poly Tetra Fluoro Ethylene (PTFE) vessels for microwave digestion, $2 \mathrm{~mL}$ of $\mathrm{HF}(50 \%)+5 \mathrm{~mL}$ of $\mathrm{HNO}_{3}(65 \%)+2 \mathrm{~mL}$ of $\mathrm{H}_{2} \mathrm{O}_{2}(30 \%)$ were added, and microwave digestion was performed for $75 \mathrm{~min}$ at a temperature of $200{ }^{\circ} \mathrm{C}$. This solution was then transferred into $125-\mathrm{mL}$ fluorinated ethylene propylene (FEP) bottles that were filled with $100 \mathrm{~g}$ of deionized water.

\section{Results}

\subsection{Bulk Coal Characteristics}

Table 1 shows the results of the proximate and related analyses of the 6 coal samples from the Wujiawan mine. Ash yields from the Wujiawan coal samples ranged from $13.60 \%$ to $31.15 \%$, with a mean ash yield of $18.72 \%$. Consequently, the coal seam was classified as low-ash coal, in accordance with Chinese Standards GB/T 15224.1-2010 [47]. The volatile matter content of the No. 5 coal samples ranged from $24.76 \%$ to $34.72 \%$, with an average of $30.13 \%$, suggesting that the No. 5 coal is medium-high-volatility coal in accordance with the standards of the MT/T 849-2000(28.01-37.00\% for medium-high-volatility coal) [48]. The moisture content ranged from $3.29 \%$ to $5.38 \%$, averaging $4.21 \%$, and qualifies as low moisture coal based on the MT/T 850-2000 $(<5 \%$ for low moisture coal) [49]. Total sulfur content for the No. 5 coal ranged from $0.50 \%$ to $3.89 \%$, with a mean of $1.35 \%$. These samples are considered to be medium-sulfur-coal, in accordance with Chinese Standards GB/T 15224.2-2010 [50], which classifies coals with a total sulfur content $1.01 \%-2.00 \%$ as medium-sulfur-coal. The average 
vitrinite reflectance was found to be $0.61 \%$ (ranging from $0.57 \%-0.63 \%$ ), indicating a bituminous coal, according to the ASTM Standard [46].

Table 1. Proximate analysis and the reflectance of the No. 5 coal seam from the Wujiawan mine.

\begin{tabular}{cccccc}
\hline Sample & $\mathbf{A}_{\mathbf{d}}$ & $\mathbf{V}_{\mathbf{d a f}}$ & $\mathbf{M}_{\mathbf{a d}}$ & $\mathbf{S}_{\mathbf{t}, \mathbf{d}}$ & $\mathbf{R}_{\mathbf{0}, \text { ran }}$ \\
\hline WJW5-1 & 17.85 & 30.46 & 4.14 & 0.63 & 0.63 \\
WJW5-3 & 22.15 & 32.68 & 4.47 & 0.79 & 0.57 \\
WJW5-4 & 31.15 & 24.76 & 3.29 & 0.50 & 0.59 \\
WJW5-6 & 13.60 & 32.70 & 4.01 & n.a. & 0.61 \\
WJW5-8 & 14.15 & 25.46 & 3.97 & 0.93 & 0.62 \\
WJW5-10 & 13.40 & 34.72 & 5.38 & 3.89 & 0.62 \\
AVE & 18.72 & 30.13 & 4.21 & 1.35 & 0.61 \\
\hline
\end{tabular}

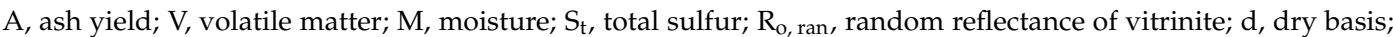
daf, dry and ash-free basis; ar, as-received basis; AVE, average concentration of the Wujiawan coal samples; n.a., not analyzed.

The No. 5 coals from the Wujiawan mine are classified as low-ash, medium-high-volatility, low moisture, medium-sulfur, bituminous coals.

\subsection{Mineralogical Characteristics}

Based on the results of XRD analysis of the LTA, optical microscopy, and SEM-EDS (see Figures 3 and 4), the No. 5 coal samples from the Wujiawan mine mainly contain kaolinite, calcite, and pyrite. In addition, trace amounts of quartz and illite were found by the SEM-EDS in the coal samples.

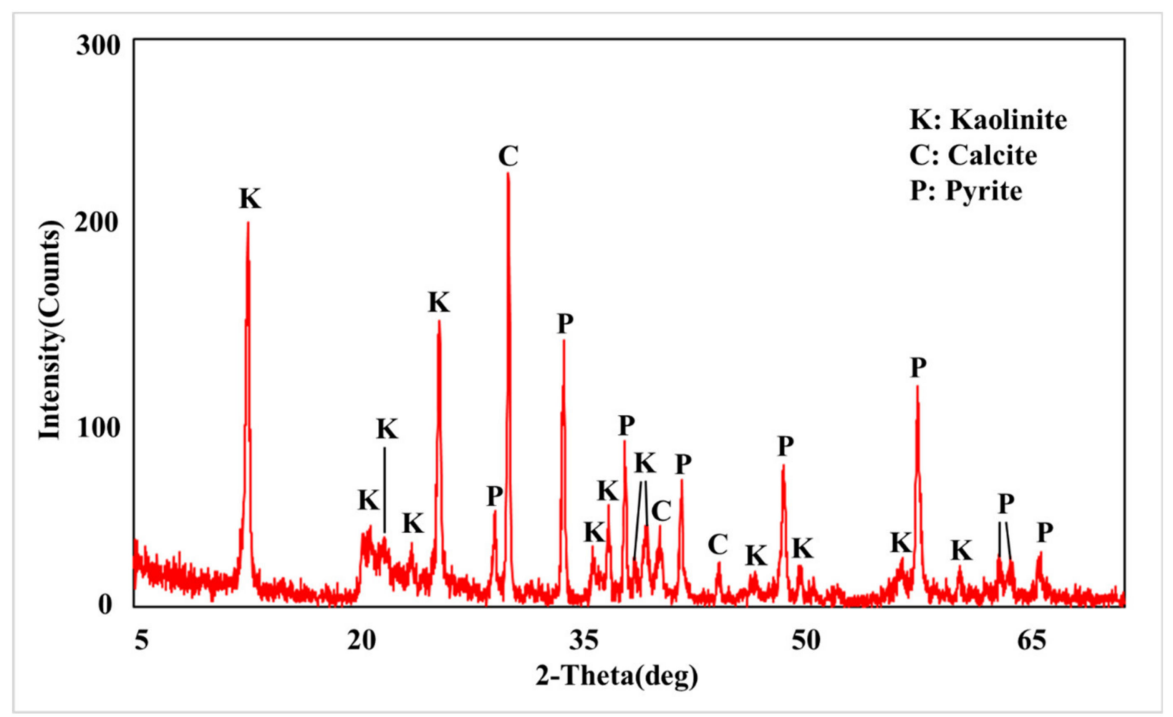

Figure 3. The XRD pattern of LTA residues of sample WJW-6 from Wujiawan mine, Datong coalfield. 

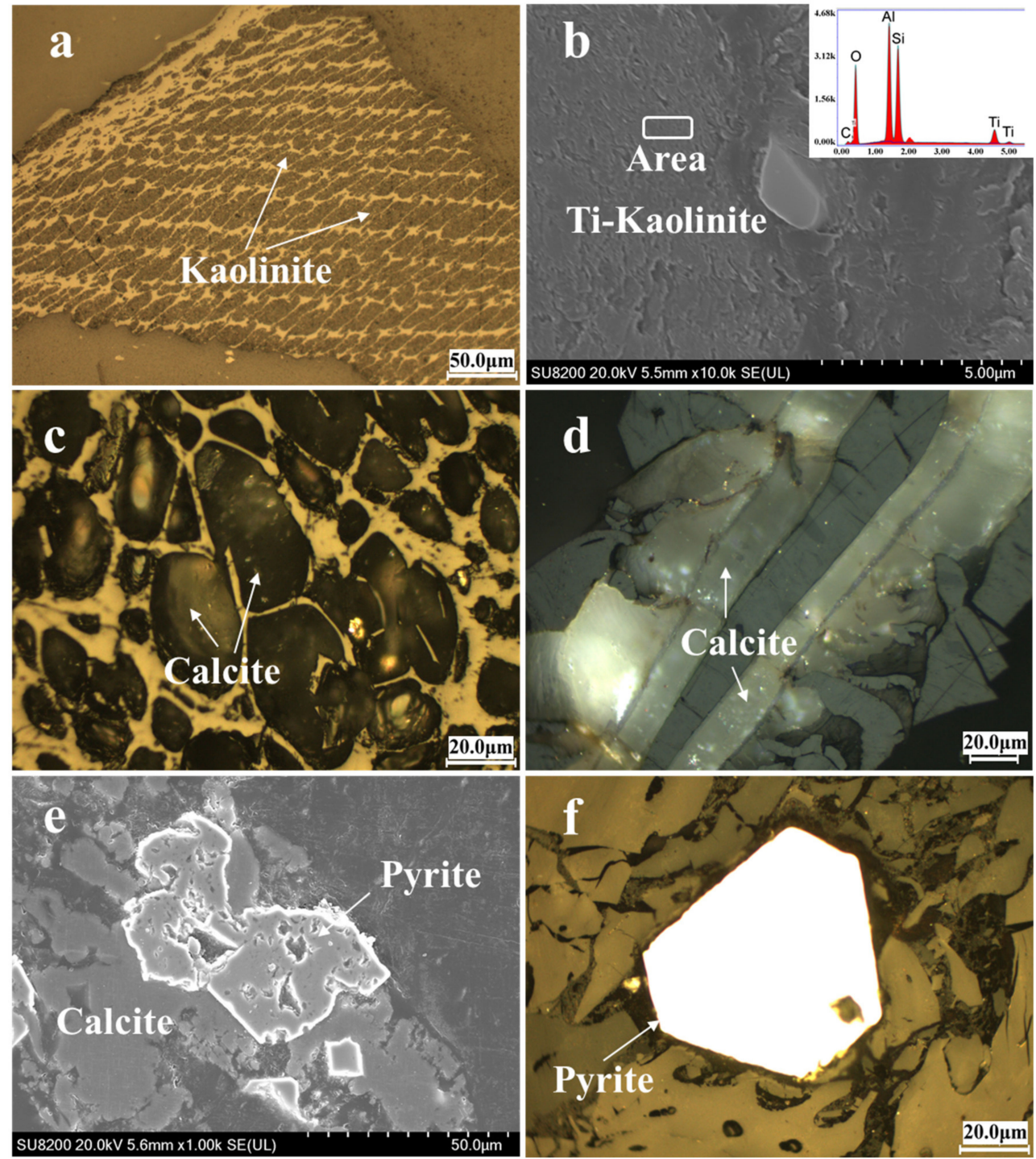

Figure 4. Distribution of the main minerals in the No. 5 coals from the Wujiawan mine, Datong coalfield. (a) Cell-filling kaolinite (reflected light); (b) fragmental Ti-bearing kaolinite and laminated kaolinite (secondary electron excitation); (c) cell-filling calcite (reflected light, oil immersion); (d) fracture-filling calcite (reflected light, oil immersion); (e) pyrite co- occurred with calcite (secondary electron excitation); and (f) pyrite crystal (reflected light, oil immersion).

\subsubsection{Kaolinite}

XRD, SEM-EDS, and optical microscopy data showed that kaolinite is the main mineral in the Wujiawan coal and mainly occurs as cell-filling (see Figure 4a). There were also trace amounts of Ti-bearing kaolinite, detected by SEM-EDS, (see Figure $4 b$ ). The cell-filling kaolinite (see Figure $4 a$ ) is common in coal $[21,36,51-53]$ and is regarded to have both authigenic and syndepositional origin $[54,55]$. Furthermore, the authigenic kaolinite may be precipitated from an acidic solution that favors the formation of authigenic kaolinite [56]. Ti-bearing kaolinite has also been reported in the late Permian coals seams located at the Songzao coalfield, in southwestern China [57]. The cell-filling Ti-bearing kaolinite indicates that $\mathrm{Ti}$ is associated with kaolinite during the authigenic process.

\subsubsection{Calcite}

Calcite is frequently formed during the authigenic, epigenetic, and postcoalification stages [58]. Various forms of calcite in the No. 5 coals from the Wujiawan mine were observed under optical 
microscopy and SEM-EDS (e.g., cell-filling (see Figure 4c), fracture-filling (see Figure 4d), and calcite-pyrite aggregates (see Figure 4e, etc.). The cell- and fracture-filling calcite indicate an authigenic origin $[59,60]$.

\subsubsection{Pyrite}

Pyrite is one of the most common minerals in coals [61,62]. The pyrite in the Wujiawan coal mostly occurs in crystal form (see Figure 4f) and co-fracture-filling with calcite (see Figure 4e). As Vejahati et al. [63] reported, the crystals of pyrite formed during the early diagenesis, whereas fissure-filled pyrite formed during the epigenetic stage. The different occurrences of pyrite indicate that the pyrite in the Wujiawan coals has both syngenetic and epigenetic origin.

\subsection{Geochemistry}

\subsubsection{Major Element Oxides}

A comparison of the proportion of major oxides in the No. 5 coal samples from the Wujiawan with the mean values of Chinese coals [64] is shown in Table 2. The data show that the $\mathrm{SiO}_{2} / \mathrm{Al}_{2} \mathrm{O}_{3}$ ratio of the No. 5 coal (1.05) and partings (1.13) are lower than the common values of Chinese coals (1.42) [64], despite the fact that oxides of the major elements in the Wujiawan coal are dominated by $\mathrm{SiO}_{2}(8.50 \%)$ and $\mathrm{Al}_{2} \mathrm{O}_{3}(8.07 \%)$ (Table 2). These values are very close to the theoretical value of kaolinite (1.18). This can be attributed to the low quartz content in the Wujiawan coal. In addition, the No. 5 coal samples are also slightly enriched in $\mathrm{P}_{2} \mathrm{O}_{5}$ and $\mathrm{MnO}$. The remaining major element oxides $\left(\mathrm{CaO}, \mathrm{TiO}_{2}, \mathrm{Fe}_{2} \mathrm{O}_{3}, \mathrm{MgO}, \mathrm{K}_{2} \mathrm{O}\right.$, and $\left.\mathrm{Na}_{2} \mathrm{O}\right)$ have values lower than the corresponding average values in Chinese coals.

Table 2. Proportion of major element oxides in the Wujiawan coal samples and their comparisons with the mean value of Chinese coals (Values are in $\mathrm{wt} \%$ on a whole coal basis).

\begin{tabular}{cccccccccccc}
\hline Sample & $\mathrm{SiO}_{2}$ & $\mathrm{Al}_{2} \mathbf{O}_{3}$ & $\mathrm{CaO}$ & $\mathbf{P}_{2} \mathrm{O}_{5}$ & $\mathrm{TiO}_{2}$ & $\mathrm{Fe}_{2} \mathrm{O}_{3}$ & $\mathbf{M g O}$ & $\mathrm{K}_{2} \mathrm{O}$ & $\mathrm{Na}_{2} \mathrm{O}$ & $\mathbf{M n O}$ & $\mathrm{SiO}_{2} / \mathrm{Al}_{2} \mathbf{O}_{3}$ \\
\hline WJW-5-1 & 8.03 & 8.08 & 0.54 & 0.49 & 0.13 & 0.13 & 0.05 & 0.01 & 0.01 & 0.002 & 0.99 \\
WJW-5-2P & 37.8 & 34.93 & 0.06 & 0.03 & 0.67 & 0.32 & 0.14 & 0.1 & 0.03 & bdl & 1.08 \\
WJW-5-3 & 9.68 & 9.2 & 2.02 & 0.03 & 0.13 & 0.27 & 0.11 & 0.04 & 0.01 & 0.011 & 1.05 \\
WJW-5-4 & 14.79 & 13.7 & 0.82 & 0.04 & 0.44 & 0.27 & 0.13 & 0.07 & 0.04 & 0.005 & 1.08 \\
WJW-5-5P & 34.69 & 31.2 & 0.09 & 0.02 & 0.39 & 0.18 & 0.15 & 0.25 & 0.05 & bdl & 1.11 \\
WJW-5-6 & 5.84 & 5.65 & 1.09 & 0.01 & 0.1 & 0.96 & 0.05 & 0.01 & 0.01 & 0.007 & 1.03 \\
WJW-5-7P & 27.37 & 24.75 & 0.1 & 0.04 & 0.89 & 0.17 & 0.12 & 0.1 & 0.03 & bdl & 1.11 \\
WJW-5-8 & 6.47 & 6.05 & 0.88 & 0.01 & 0.13 & 0.2 & 0.05 & 0.01 & 0.01 & 0.004 & 1.07 \\
WJW-5-9P & 33.14 & 29.82 & 0.14 & 0.01 & 0.32 & 0.18 & 0.15 & 0.11 & 0.02 & bdl & 1.11 \\
WJW-5-10 & 6.21 & 5.75 & 0.16 & 0.01 & 0.18 & 0.62 & 0.06 & 0.01 & 0.01 & 0.066 & 1.08 \\
WJW-5-11P & 40.5 & 31.9 & 0.21 & 0.05 & 0.93 & 0.91 & 0.36 & 0.85 & 0.05 & 0.002 & 1.27 \\
WJW-5-12F & 35.47 & 32.76 & 0.08 & 0.02 & 1.13 & 0.21 & 0.12 & 0.07 & 0.03 & bdl & 1.08 \\
AVE-C & 8.50 & 8.07 & 0.92 & 0.10 & 0.19 & 0.41 & 0.08 & 0.03 & 0.02 & 0.02 & 1.05 \\
AVE-P & 34.83 & 30.89 & 0.11 & 0.03 & 0.72 & 0.33 & 0.17 & 0.25 & 0.04 & bdl & 1.13 \\
*China & 8.47 & 5.98 & 1.23 & 0.092 & 0.33 & 4.85 & 0.22 & 0.19 & 0.16 & 0.015 & 1.42 \\
\hline
\end{tabular}

AVE-C: average of coal samples; AVE-P: average of parting samples; bdl: below detection limit; and ${ }^{*}$ China: average content of major-element oxides for common Chinese coals are from Dai et al. [64].

\subsubsection{Trace Elements}

Table 3 lists the concentration of trace elements in the No. 5 coal from the Wujiawan mine and their comparison with other world hard coals [65]. The results indicate that Li is highly enriched in the No. 5 coal at the Wujiawan mine, with a concentration coefficient (CC, the ratio of element concentration in Wujiawan coal and the corresponding average value in world hard coals) $>5$ (see Figure $5 \mathrm{a}$ ). Gallium, $\mathrm{Zr}$, $\mathrm{Nb}, \mathrm{Hf}$, Ta, and Th are enriched $(2<\mathrm{CC}<5)$ (see Figure $5 \mathrm{a})$, while some elements, such as Be, Sc, Cd, $\mathrm{W}, \mathrm{Pb}$, and $\mathrm{U}(0.5<\mathrm{CC}<2)$, are at levels near to average values of world hard coals (see Figure $5 \mathrm{a}$ ). The remaining elements are underrepresented in the No. 5 coals (see Figure 5a). 
Table 3. Contents of trace elements in the No. 5 coal from the Wujiawan mine, Datong coalfield ( $\mu \mathrm{g} / \mathrm{g}$, on whole coal basis).

\begin{tabular}{|c|c|c|c|c|c|c|c|c|c|c|c|c|c|c|c|c|c|c|c|c|c|c|c|c|}
\hline Samples & $\mathrm{Li}$ & Be & Sc & V & $\mathrm{Cr}$ & Co & $\mathrm{Ni}$ & $\mathrm{Cu}$ & $\mathrm{Zn}$ & Ga & $\mathbf{R b}$ & $\mathrm{Zr}$ & $\mathrm{Nb}$ & Mo & $\mathrm{Cd}$ & Cs & Ва & $\mathrm{Hf}$ & Ta & W & $\mathbf{P b}$ & Bi & Th & U \\
\hline WJW-5-1 & 97.4 & 3.17 & 6.8 & 18.3 & 4.6 & 0.5 & 1.8 & 107 & 6.6 & 16.6 & 0.4 & 140.1 & 7.06 & 0.57 & 0.08 & 0.06 & 63.0 & 3.71 & 0.36 & 0.32 & 15.6 & 0.33 & 7.29 & 2.90 \\
\hline & & & & & & & & & & & & & & & & & & .10 & & & & 89 & & 38 \\
\hline & & & 4.9 & & & & & 3 & & & & & & & & & & & & & & & & .03 \\
\hline & 2.9 & 3.34 & 7.5 & & & & 1. & & & & & & & & & & & & & & & & & 42 \\
\hline & & & 3.9 & & & & & & & & & & & & & & & & & & & & & .02 \\
\hline & & & 3. & & & & 1 & & & & & & & & & & & & & & & & & \\
\hline & & & & & & & & & & & & & & & & & & & & & & & & 36 \\
\hline & & & 3. & & & & 1 & & & & 0 & & & & & & & & & & & & & 84 \\
\hline & & & & & & & & & & & & & & & & & & & & & & & & 07 \\
\hline & & & 3.4 & & & & 2 & & 4.3 & & & & & & & & 2.9 & & & & & & & 3.29 \\
\hline & & & & & & & & & & & & & & & & & & & & & & & & 4.41 \\
\hline WJW-5-12F & 345.9 & & 9.4 & & 8 & & 3. & & & & 2.0 & & & & & & & 10.59 & & & & & 20.62 & 5.44 \\
\hline & & & & & & & & & & & & & & & & & & & & & & & & 3.10 \\
\hline AVE-P & 234.88 & 1.59 & 7.60 & 36.92 & 23.50 & 1.47 & 5.48 & 13.00 & 16.72 & 30.42 & 9.58 & 244.48 & 25.49 & 1.7 & & 0.99 & 33.55 & 6.94 & & 2.99 & 12.82 & & 17.24 & 3.61 \\
\hline & 10 & 1.6 & 3.90 & 28.00 & 16 & 5.1 & 13 & 16 & 23 & 5.8 & 8.3 & 36.00 & 3.70 & 2.20 & & & & 1.2 & 0. & 1.10 & 7.8 & 97 & 3.30 & 2.4 \\
\hline & 54 & 3 & 15 & 120 & 110 & 19 & 49 & 36 & 89 & 16 & 133 & 190 & 11 & 1.6 & 0.91 & 13 & 460 & 120 & 110 & 2.6 & 14 & 0.38 & 4.3 & 4.3 \\
\hline
\end{tabular}

${ }^{1}$ World coals, average content of trace elements for world coals are from Ketris and Yudovich [65]; ${ }^{2}$ world clays, average content of trace elements for world clays are from Yaroshevsky [66]; AVE-C, average content of coal samples; and AVE-P, average content of parting samples. 


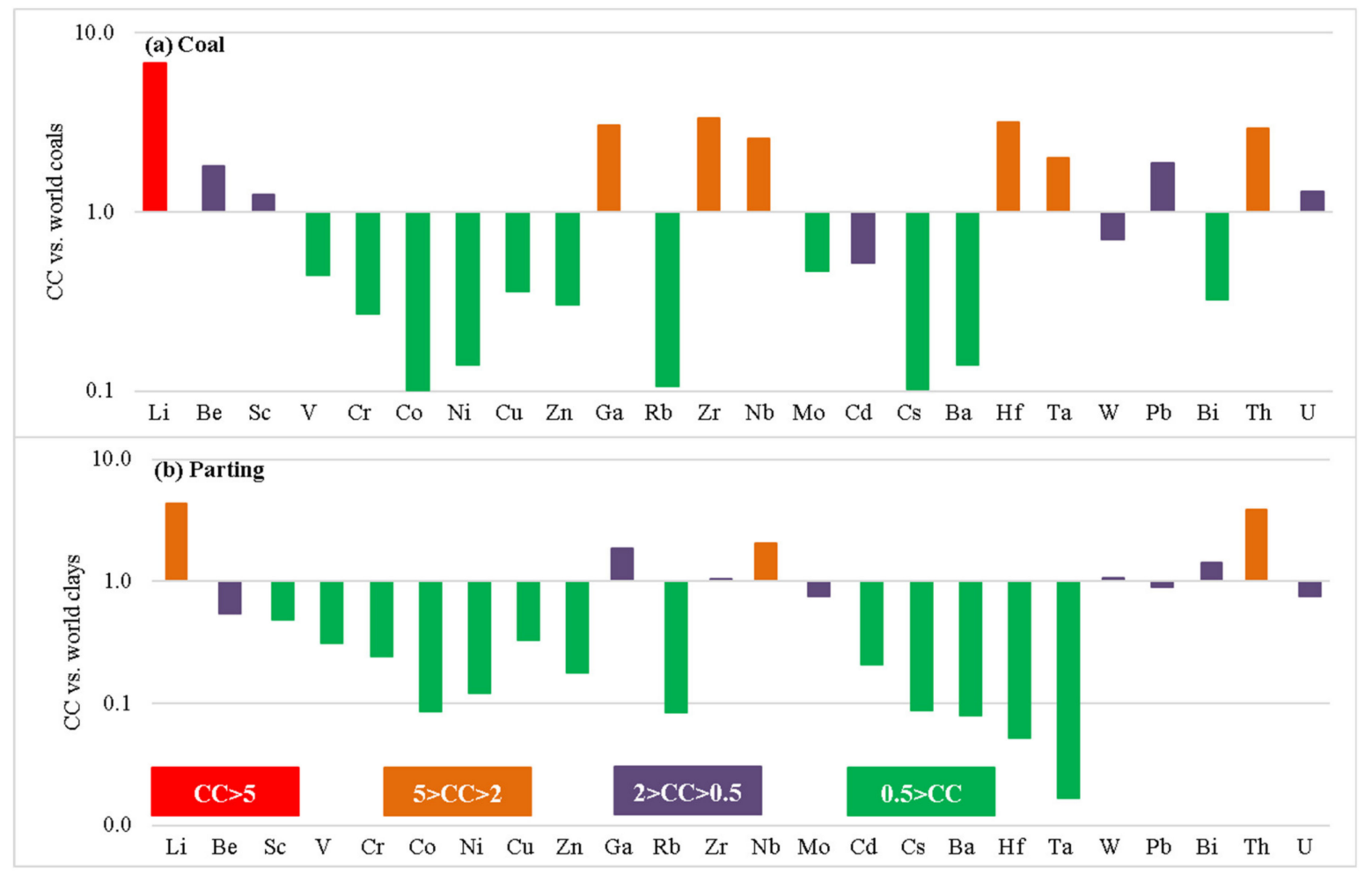

Figure 5. Concentration coefficients of trace elements in coals (a) and partings (b) from the Wujiawan mine at Datong coalfield, normalized by the average concentrations of trace elements in world hard coals and world clays, respectively.

Lithium, $\mathrm{Nb}$, and Th in the partings of the No. 5 coal seam are enriched (see Figure $5 b$ ) compared to world clays [66]. Values for $\mathrm{Be}, \mathrm{Ga}, \mathrm{Zr}, \mathrm{Mo}, \mathrm{W}, \mathrm{Pb}, \mathrm{Bi}$, and $\mathrm{U}$ approach the mean values for world clays, and the remaining elements are depleted when compared to world clays.

\subsubsection{Rare Earth Elements and Yttrium (REY)}

The concentration of REY in the Wujiawan coal varied from 45.14 to $372.60 \mu \mathrm{g} / \mathrm{g}$, with a mean of $157.86 \mu \mathrm{g} / \mathrm{g}$ (Table 4). This is around 2.5 times higher than the average value of world hard coals $(68.41 \mu \mathrm{g} / \mathrm{g})$. The average content of REY in the parting samples $(151.22 \mu \mathrm{g} / \mathrm{g})$ was slightly lower than that in the coal samples (Table 4). The REY content in coal samples WJW-1 (372.60 $\mu \mathrm{g} / \mathrm{g}$ ) and WJW-4 $(194.09 \mu \mathrm{g} / \mathrm{g})$ was much higher than for other coal samples. Furthermore, the REY content in the parting samples WJW-7 and WJW-11 were 393.48 and $220.34 \mu \mathrm{g} / \mathrm{g}$, respectively, and were the highest two samples in the No. 5 coal seam.

In the present study, three types of REY — light (LREY: La, Ce, Pr, Nd, and Sm), medium (MREY: Eu, $\mathrm{Gd}, \mathrm{Tb}, \mathrm{Dy}$, and Y), and heavy (HREY: Ho, Er, Tm, Yb, and Lu) - were identified in accordance with the Seredin and Dai's classification parameters [4]. The concentration of REY was normalized by the UCC to classify the enrichment types of REY distribution. Seredin and Dai [67] identify the enrichment types of REY as L-type (light-REY: $\mathrm{La}_{N} / \mathrm{Lu}_{N}>1$ ), M-type (medium-REY: $\mathrm{La}_{N} / \mathrm{Sm}_{\mathrm{N}}<1, \mathrm{Gd}_{\mathrm{N}} / \mathrm{Lu}_{\mathrm{N}}>1$ ), and $\mathrm{H}$-type (heavy REY: $\mathrm{La}_{\mathrm{N}} / \mathrm{Lu}_{\mathrm{N}}<1$ ) in this coal. At the same time, a mixed type (H-M-type) also occurs in the No. 5 coal. The Eu anomalies $\left(\mathrm{Eu}_{\mathrm{N}} / \mathrm{Eu}_{\mathrm{N}}{ }^{*}\right)$ and $\mathrm{Gd}$ anomalies $\left(\mathrm{Gd}_{\mathrm{N}} / \mathrm{Gd}_{\mathrm{N}}{ }^{*}\right)$ were calculated according to formulae 4 and 5 from Dai et al. [68]. 
Table 4. Concentrations of Rare Earth Elements and Y (REY) in the coals and partings from the No. 5 coal seam.

\begin{tabular}{|c|c|c|c|c|c|c|c|c|c|c|c|c|c|c|}
\hline Sample & WJW5-1 & WJW5-2P & WJW5-3 & WJW5-4 & WJW5-5P & WJW5-6 & WJW5-7P & WJW5-8 & WJW5-9P & WJW5-10 & WJW5-11P & WJW-12F & AVE-C & AVE-P \\
\hline $\mathrm{La}$ & 107.82 & 12.19 & 18.63 & 36.12 & 18.71 & 16.74 & 92.11 & 18.08 & 7.92 & 9.59 & 47.45 & 5.26 & 34.50 & 30.61 \\
\hline $\mathrm{Ce}$ & 151.46 & 30.02 & 40.89 & 73.38 & 36.36 & 32.48 & 164.69 & 35.84 & 14.92 & 20.34 & 84.29 & 17.82 & 59.06 & 58.02 \\
\hline $\operatorname{Pr}$ & 15.60 & 3.34 & 4.69 & 7.95 & 3.70 & 3.58 & 18.06 & 3.94 & 1.52 & 2.27 & 9.12 & 2.27 & 6.34 & 6.33 \\
\hline $\mathrm{Nd}$ & 51.86 & 11.38 & 17.36 & 28.23 & 12.31 & 12.88 & 59.57 & 13.69 & 4.90 & 8.14 & 30.50 & 8.44 & 22.03 & 21.18 \\
\hline $\mathrm{Sm}$ & 8.73 & 2.47 & 3.86 & 5.74 & 2.12 & 2.71 & 10.32 & 2.72 & 0.85 & 1.84 & 5.27 & 2.31 & 4.27 & 3.89 \\
\hline $\mathrm{Eu}$ & 1.42 & 0.45 & 0.67 & 0.97 & 0.34 & 0.50 & 1.67 & 0.54 & 0.17 & 0.45 & 1.31 & 0.57 & 0.76 & 0.75 \\
\hline $\mathrm{Gd}$ & 8.94 & 2.57 & 3.82 & 5.74 & 2.09 & 2.72 & 10.05 & 2.80 & 0.99 & 1.90 & 5.50 & 2.67 & 4.32 & 3.98 \\
\hline $\mathrm{Tb}$ & 0.89 & 0.54 & 0.71 & 0.90 & 0.26 & 0.47 & 1.14 & 0.42 & 0.17 & 0.38 & 0.79 & 0.70 & 0.63 & 0.60 \\
\hline Dy & 4.04 & 3.39 & 4.15 & 4.75 & 1.51 & 2.61 & 5.15 & 2.51 & 1.30 & 2.24 & 4.64 & 4.24 & 3.38 & 3.37 \\
\hline $\mathrm{Y}$ & 16.71 & 17.83 & 21.81 & 23.20 & 8.30 & 14.78 & 23.55 & 14.57 & 9.51 & 13.66 & 23.98 & 20.54 & 17.45 & 17.29 \\
\hline Ho & 0.76 & 0.75 & 0.90 & 1.00 & 0.34 & 0.58 & 1.01 & 0.57 & 0.35 & 0.51 & 1.04 & 0.92 & 0.72 & 0.73 \\
\hline $\mathrm{Er}$ & 2.03 & 1.97 & 2.38 & 2.65 & 0.93 & 1.57 & 2.76 & 1.57 & 1.06 & 1.43 & 2.81 & 2.31 & 1.94 & 1.97 \\
\hline $\mathrm{Tm}$ & 0.28 & 0.31 & 0.38 & 0.43 & 0.15 & 0.25 & 0.41 & 0.26 & 0.19 & 0.24 & 0.46 & 0.37 & 0.31 & 0.31 \\
\hline $\mathrm{Yb}$ & 1.79 & 1.81 & 2.28 & 2.67 & 0.89 & 1.49 & 2.60 & 1.56 & 1.13 & 1.51 & 2.79 & 2.23 & 1.89 & 1.91 \\
\hline $\mathrm{Lu}$ & 0.26 & 0.27 & 0.34 & 0.39 & 0.13 & 0.23 & 0.38 & 0.24 & 0.17 & 0.22 & 0.41 & 0.32 & 0.28 & 0.28 \\
\hline REY & 372.60 & 89.29 & 122.86 & 194.09 & 88.14 & 93.58 & 393.48 & 99.30 & 45.14 & 64.72 & 220.34 & 70.94 & 157.86 & 151.22 \\
\hline $\mathrm{La}_{\mathrm{N}} / \mathrm{Lu}_{\mathrm{N}}$ & 4.41 & 0.49 & 0.59 & 0.99 & 1.49 & 0.79 & 2.56 & 0.80 & 0.51 & 0.47 & 1.24 & 0.18 & 1.34 & 1.08 \\
\hline $\mathrm{La}_{\mathrm{N}} / \mathrm{Sm}_{\mathrm{N}}$ & 1.85 & 0.74 & 0.72 & 0.94 & 1.33 & 0.93 & 1.34 & 1.00 & 1.40 & 0.78 & 1.35 & 0.34 & 1.04 & 1.08 \\
\hline $\mathrm{Gd}_{\mathrm{N}} / \mathrm{Lu}_{\mathrm{N}}$ & 2.89 & 0.82 & 0.95 & 1.25 & 1.31 & 1.02 & 2.20 & 0.98 & 0.50 & 0.73 & 1.14 & 0.70 & 1.30 & 1.11 \\
\hline $\mathrm{Eu}_{\mathrm{N}} / \mathrm{Eu}_{\mathrm{N}}{ }^{*}$ & 0.91 & 0.80 & 0.81 & 0.83 & 0.87 & 0.88 & 0.89 & 0.98 & 0.93 & 1.08 & 1.25 & 0.92 & 0.92 & 0.94 \\
\hline $\mathrm{Gd}_{N} / \mathrm{Gd}_{\mathrm{N}}{ }^{*}$ & 1.49 & 0.90 & 0.98 & 1.11 & 1.29 & 1.03 & 1.35 & 1.15 & 1.09 & 0.94 & 1.19 & 0.78 & 1.12 & 1.10 \\
\hline Type & L-type & H-type & H-type & H-M-type & L-type & H-M-type & L-type & H-type & H-type & H-type & L-type & H-type & - & - \\
\hline
\end{tabular}

AVE-C: average of coal samples; AVE-P: average of parting samples; REY: the sum of rare earth elements and yttrium; subscript N indicates values are normalized by the average content of the Upper Continental Crust (UCC) [4,5]; $\mathrm{Eu}_{N} / \mathrm{Eu}_{\mathrm{N}}^{*}=\mathrm{Eu}_{\mathrm{N}} /\left(0.67 \mathrm{Sm}_{\mathrm{N}}+0.33 \mathrm{~Tb}_{\mathrm{N}}\right) ;$ and $\mathrm{Gd}_{\mathrm{N}} / \mathrm{Gd}_{\mathrm{N}}{ }^{*}=\mathrm{Gd}_{\mathrm{N}} /\left(0.33 \mathrm{Sm}_{\mathrm{N}}+0.67 \mathrm{~Tb}_{\mathrm{N}}\right)[68]$. 
The REY enrichment patterns in No. 5 coals (including partings) were mainly characterized by H-type (see Figure 6a) and L-type enrichment (see Figure 6b). Only the WJW-4 and WJW-6 samples were found to be of the M-H-REY type (see Figure 6c).
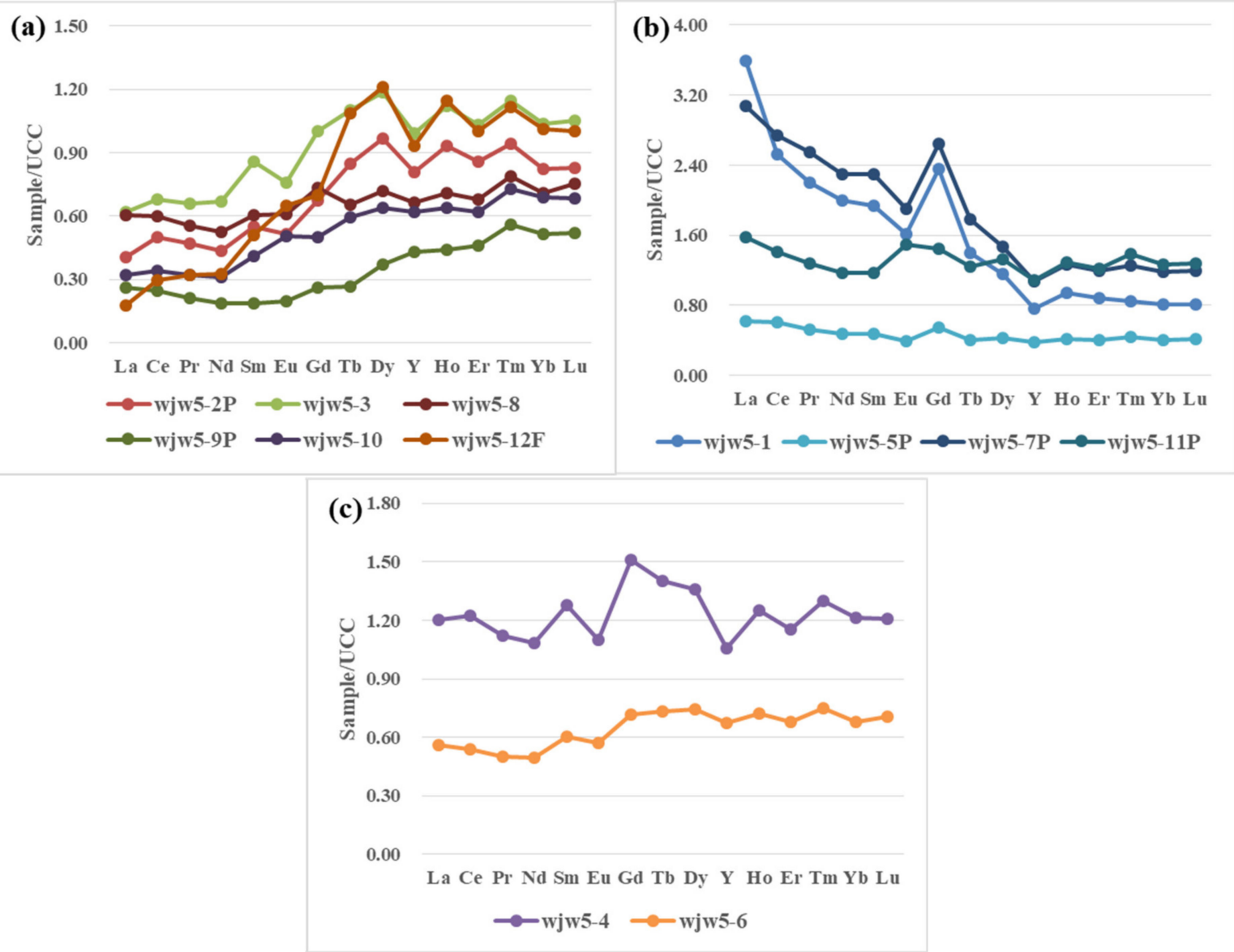

Figure 6. REY distribution patterns in the No. 5 coal (including coal and parting samples), normalized to the upper continental crust. (a) Patterns of H-type enrichment; (b), patterns of L-type enrichment; and (c), patterns of M-H-REY enrichment.

\section{Discussion}

\subsection{Affinity of the Elements}

The elements' affinity in coal for organic or inorganic matter may be reflected in the correlation between the element concentrations and ash yield [69,70]. Numerous studies have discussed the characteristics of elements in coal, e.g., occurrence, affinity, and genesis, by using correlation analysis [71-73]. However, the analysis method of correlation analysis should also be noted, because element correlations are dependent on the homogeneity of the population, the number of samples, and the elements determined. A good selection of samples would decrease the possibility that the statistical manipulation of the data would suggest an impossible element relationships [70,74]. Figure 7a,b shows the correlations (r) of ash yield with major element oxides, and trace elements, respectively. 

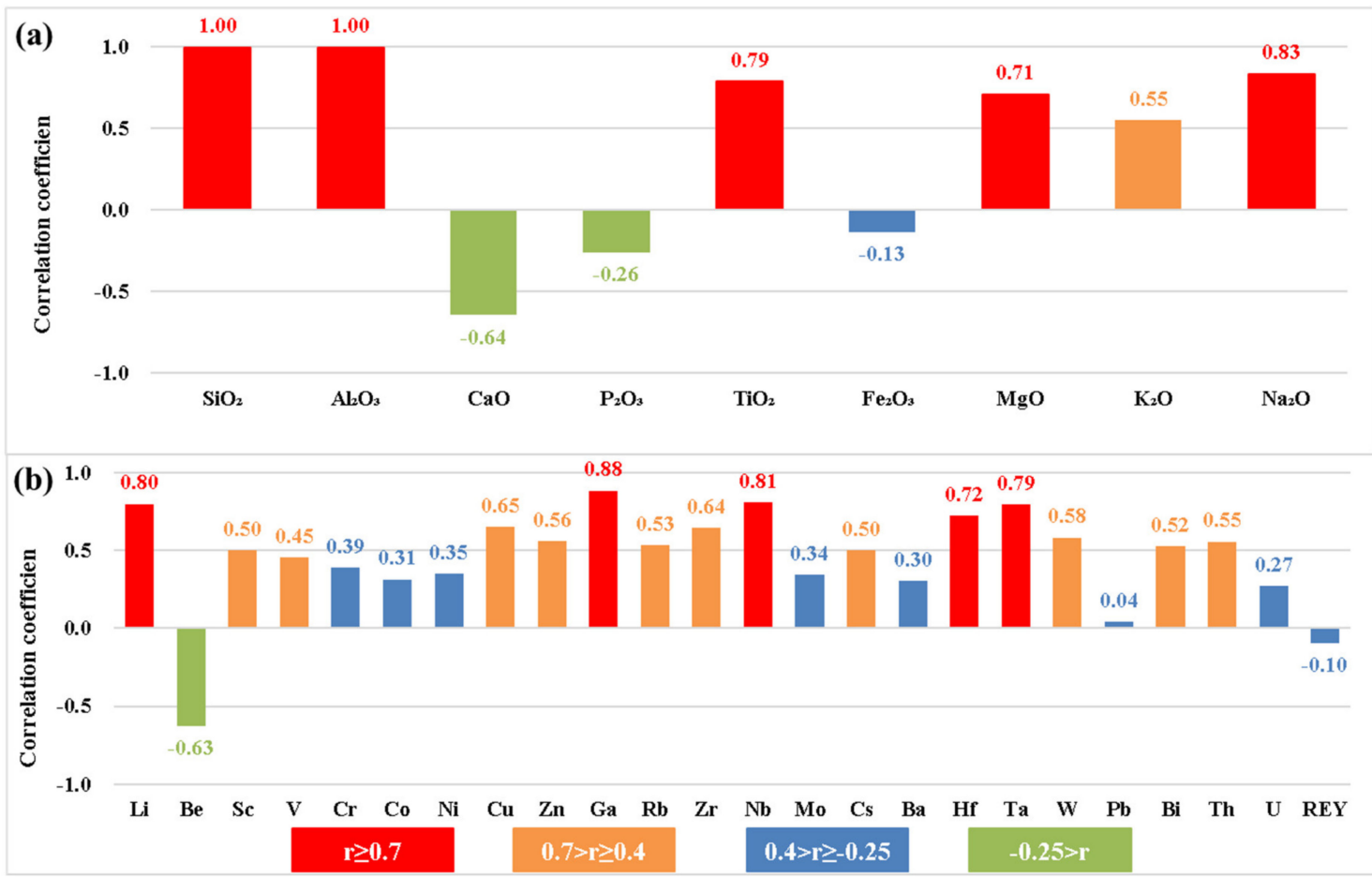

Figure 7. Correlation coefficients between ash yield and elements in Wujiawan coal. (a) The correlation coefficients between ash yield and major elements; (b) the correlation coefficients between ash yield and trace elements.

Four groups (Groups 1-4) of elements have been recognized, based on the relationship between their ash yield and elemental concentrations:

Group 1 consists of $\mathrm{Al}_{2} \mathrm{O}_{3}, \mathrm{SiO}_{2}, \mathrm{TiO}_{2}, \mathrm{MgO}, \mathrm{Na}_{2} \mathrm{O}, \mathrm{Li}, \mathrm{Ga}, \mathrm{Nb}, \mathrm{Hf}$, and Ta. The concentrations of elements from this group are significantly correlated with the ash yield, suggesting a high inorganic affinity. Furthermore, the strong affinity between $\mathrm{Al}_{2} \mathrm{O}_{3}$ and $\mathrm{SiO}_{2}(0.99$, Table 5) suggests that the kaolinite in the samples is the most important carrier of $\mathrm{Al}_{2} \mathrm{O}_{3}$ and $\mathrm{SiO}_{2}$. This is supported by the high content of kaolinite and simultaneously low quartz content, as obtained from the results of the optical microscopy, XRD, and SEM-EDS. Additionally, the $\mathrm{TiO}_{2}$ in the No. 5 coal has strong and similar correlations with $\mathrm{Al}_{2} \mathrm{O}_{3}$ and $\mathrm{SiO}_{2}(\mathrm{r}=0.79$ and 0.78 , respectively), showing that kaolinite is also the main carrier of Ti. This is also supported by the EDS-detectable Ti within kaolinite under SEM-EDS, as well as the low content of titanium oxide minerals such as rutile, brookite, and anatase in this coal. The Ti-bearing kaolinite in coal from the Songzao coalfield and Hunchun coalfield, in China, has been reported by Zhao et al. [19] and Dai et al. [75], respectively. Both investigations suggested that Ti occurs as submicron oxides in kaolinite. The remaining elements in this group $\left(\mathrm{MgO}, \mathrm{Na}_{2} \mathrm{O}, \mathrm{Li}, \mathrm{Ga}\right.$, $\mathrm{Nb}, \mathrm{Hf}$, and Ta) also have high correlations with $\mathrm{Al}_{2} \mathrm{O}_{3}$ and $\mathrm{SiO}_{2}\left(\mathrm{r}_{(\mathrm{Al}, \mathrm{Si})}>0.7\right.$, Table 5), along with an absence of accessory minerals (e.g., zircon), indicating an aluminosilicate affinity mainly associated with clay minerals.

Group 2 includes the following elements: $\mathrm{K}_{2} \mathrm{O}, \mathrm{Sc}, \mathrm{V}, \mathrm{Cu}, \mathrm{Zn}, \mathrm{Rb}, \mathrm{Zr}, \mathrm{Cs}, \mathrm{W}, \mathrm{Bi}$, and Th. This group has a relatively low inorganic affinity compared to Group 1 , but relatively higher $\mathrm{r}$ values than other groups $\left(r_{\text {ash }}=0.4-0.69\right.$, Figure $\left.7 a, b\right)$. Furthermore, elements in this group have moderate correlations with $\mathrm{SiO}_{2}$ and $\mathrm{Al}_{2} \mathrm{O}_{3}\left(\mathrm{r}_{(\mathrm{Al}, \mathrm{Si})}=0.4-0.69\right.$, Table 5), indicating a moderate aluminosilicate mineral affinity.

Group 3 consists of $\mathrm{Fe}_{2} \mathrm{O}_{3}, \mathrm{Cr}, \mathrm{Co}, \mathrm{Ni}, \mathrm{Mo}, \mathrm{Ba}, \mathrm{Pb}, \mathrm{U}$, and REY. The $\mathrm{r}$ values of the elements in this group vary from -0.13 to 0.39 (see Figure $7 a$ and $b$ ), suggesting either organic or inorganic affinities. Among these elements, $\mathrm{Cr}$ has a relatively high correlation coefficient with ash yield $(\mathrm{r}=0.39$, see Figure $7 \mathrm{~b}$ ), suggesting that $\mathrm{Cr}$ has probably more affinity for inorganic matter; this is further supported by relatively high correlation with $\mathrm{SiO}_{2}(0.44)$ and $\mathrm{Al}_{2} \mathrm{O}_{3}(0.34$, Table 5). 
Table 5. Correlation coefficients between the concentrations of trace and major elements in the Wujiawan coal and selected elements.

\begin{tabular}{|c|c|c|c|c|c|c|}
\hline \multicolumn{7}{|c|}{ Aluminosilicate Affinity } \\
\hline \multirow{2}{*}{$\mathrm{r}_{(\mathrm{Al}, \mathrm{Si})}>0.7$} & $\operatorname{Li}(0.78,0.82)$ & \multirow{2}{*}{$\begin{array}{c}\mathrm{Ga}(0.88,0.87) \\
\mathrm{TiO}_{2}(0.79,0.78)\end{array}$} & \multirow{2}{*}{\multicolumn{2}{|c|}{$\begin{array}{c}\mathrm{Nb}(0.79,0.82) \\
\mathrm{MgO}(0.74,0.67)\end{array}$}} & \multirow{2}{*}{\multicolumn{2}{|c|}{$\begin{array}{c}\mathrm{Hf}(0.71,0.74) \\
\mathrm{Na}_{2} \mathrm{O}(0.84,0.83)\end{array}$}} \\
\hline & Ta $(0.77,0.82)$ & & & & & \\
\hline \multirow{3}{*}{$\mathrm{r}_{(\mathrm{Al}, \mathrm{Si})}=0.4-0.69$} & $\mathrm{~K}_{2} \mathrm{O}(0.60,0.50)$ & Sc $(0.53,0.47)$ & \multicolumn{2}{|c|}{$\mathrm{V}(0.50,0.41)$} & \multicolumn{2}{|c|}{ Cr $(0.44,0.34)$} \\
\hline & $\mathrm{Cu}(0.67,0.64)$ & $\mathrm{Zn}(0.59,0.52)$ & \multicolumn{2}{|c|}{$\mathrm{Rb}(0.58,0.49)$} & \multicolumn{2}{|c|}{$\mathrm{Zr}(0.62,0.66)$} \\
\hline & Cs $(0.55,0.46)$ & $\mathrm{W}(0.58,0.59)$ & \multicolumn{2}{|c|}{$\mathrm{Bi}(0.51,0.54)$} & & $(0.55,0.57)$ \\
\hline \multicolumn{7}{|c|}{ Correlation Coefficients between Selected Elements } \\
\hline $\mathrm{Al}_{2} \mathrm{O}_{3}-\mathrm{SiO}_{2}=0.99$ & $\mathrm{CaO}-\mathrm{SiO}_{2}=-0.65$ & $\mathrm{CaO}-\mathrm{Al}_{2} \mathrm{O}_{3}=-0.66$ & $\mathrm{Li}-\mathrm{Zr}(0.90)$ & $\mathrm{Li}-\mathrm{Nb}$ & & Li-Hf (0.97) \\
\hline $\mathrm{Li}-\mathrm{Ta}(0.87)$ & $\mathrm{Li}-\mathrm{Bi}(0.82)$ & $\mathrm{Ga}-\mathrm{TiO}_{2}(0.70)$ & $\mathrm{Zr}-\mathrm{Nb}(0.92)$ & $\mathrm{Zr}-\mathrm{H}$ & & $\mathrm{Zr}-\mathrm{Ta}(0.80)$ \\
\hline $\mathrm{Zr}-\mathrm{Th}(0.65)$ & $\mathrm{Nb}-\mathrm{Ta}(0.95)$ & $\mathrm{Nb}-\mathrm{Hf}(0.96)$ & $\mathrm{Nb}-\mathrm{Th}(0.76)$ & Hf-Ta & & Hf-Th $(0.74)$ \\
\hline Ta-Th (0.83) & $\mathrm{TiO}_{2}-\mathrm{Zr}(0.81)$ & $\mathrm{TiO}_{2}-\mathrm{Nb}(0.86)$ & $\mathrm{TiO}_{2}-\mathrm{Hf}(0.82)$ & $\mathrm{TiO}_{2}-\mathrm{T}$ & & $\mathrm{TiO}_{2}-\mathrm{Th}(0.83)$ \\
\hline
\end{tabular}

Group 4 only includes $\mathrm{CaO}, \mathrm{P}_{2} \mathrm{O}_{5}$, and $\mathrm{Be}$; the correlation coefficient values between them and ash yield range from -0.64 to -0.26 . The relatively low correlation coefficient of these elements with ash yield showing an organic affinity.

\subsection{Sediment Source Region}

The ratio of $\mathrm{Al}_{2} \mathrm{O}_{3} / \mathrm{TiO}_{2}$ could be an indicator of the source region for the coal deposits [76], since it may remain almost unchanged during surface weathering and alteration [77-79]. Generally, the value of $\mathrm{Al}_{2} \mathrm{O}_{3} / \mathrm{TiO}_{2}$ for sediments derived from mafic is 3-8, from intermediate is 8-21, and from felsic rocks is 21-70 [5]. Figure 8a shows that the ratios of $\mathrm{Al}_{2} \mathrm{O}_{3} / \mathrm{TiO}_{2}$ for all samples in the No. 5 coal (including parting and floor samples) are higher than 21 (see Figure 8a), suggesting a felsic sediment source.
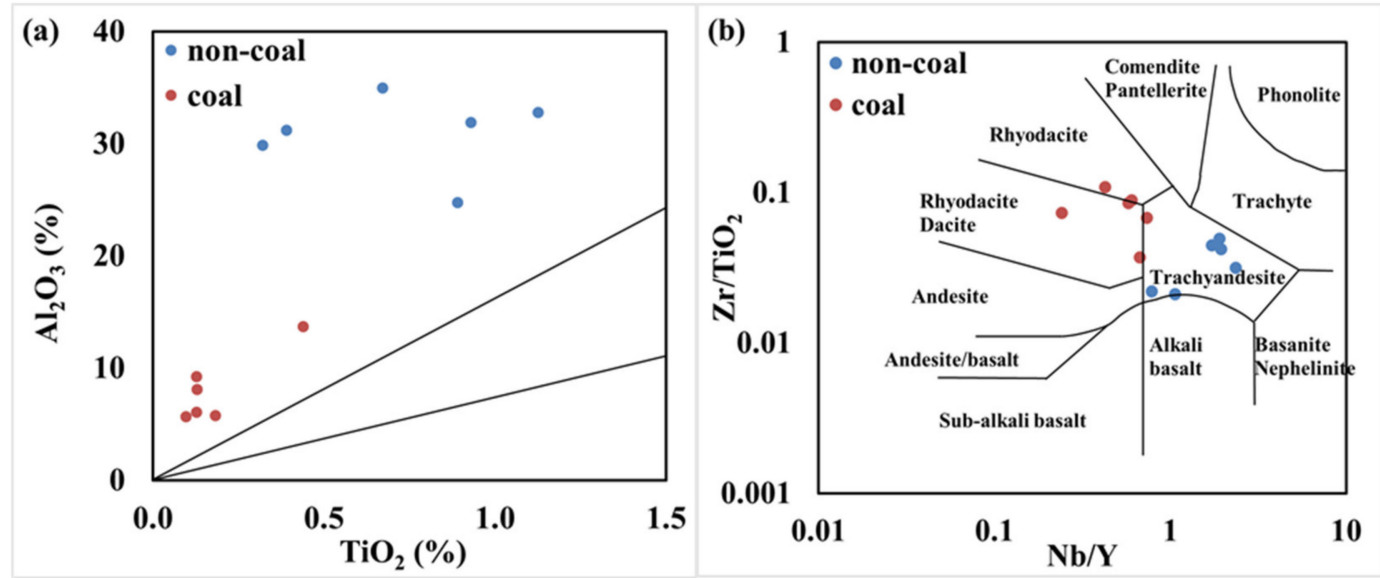

Figure 8. Figure of relationship between elements in Wujiawan coal. (a) Relationship between $\mathrm{Al}_{2} \mathrm{O}_{3}$ and $\mathrm{TiO}_{2}$. The lower and upper diagonal lines represent $\mathrm{Al}_{2} \mathrm{O}_{3} / \mathrm{TiO}_{2}=8$ and $\mathrm{Al}_{2} \mathrm{O}_{3} / \mathrm{TiO}_{2}=21$, respectively. (b) Figure of the ratio of $\mathrm{Zr} / \mathrm{TiO}_{2}$ verus $\mathrm{Nb} / \mathrm{Y}$.

The figure of $\mathrm{Zr} / \mathrm{TiO}_{2}$ verus $\mathrm{Nb} / \mathrm{Y}$ (see Figure $8 \mathrm{~b}$ ) for all the samples from the No. 5 coal were studied following Winchester and Floyd [80]. Most of the coal samples fall into the area of rhyodacite/dacite and rhyodacite, suggesting a felsic sediment source, whereas all the noncoal (parting and floor) samples fall into the field of trachyandesite; this is further evidence that the felsic composition dominated the sediment source region at the peat swamp. 
The granite and gneiss of the Yinshan Oldland, which are specially enriched in Li, Ga, and high field strength elements (HFSEs, elements whose ions have a small radius and high charge, and therefore, high associated electric field [81]), have been suggested to be the main source of $\mathrm{Li}, \mathrm{Ga}$, and some of HFSEs in the coals from the Jungar coalfield and Ningwu coalfield, which are adjacent to Datong coalfield $[10,71,82-84]$. Therefore, the strong correlations between Li, Ga, and HFSEs in this study may indicate that the Yinshan Oldland is the potential source region of sediment of the coal from the Datong coalfield. This inference is further supported by Dai et al. who found that the average Li content in the middle Proterozoic K-feldspar granite of the Yinshan Oldland is $26 \mu \mathrm{g} / \mathrm{g}$ [10] (this is around two times higher than world hard coals). Meanwhile, Dai et al. reported that coals with felsic compositions in the source of sediment region have a high content of lithophile elements [23]. The ratio of $\mathrm{Al}_{2} \mathrm{O}_{3} / \mathrm{TiO}_{2}$, along with the results from $\mathrm{Zr} / \mathrm{TiO}_{2} \mathrm{vs}$. $\mathrm{Nb} / \mathrm{Y}$, suggest that the region of the source of sediment for all the samples (coals, partings, and floor) is dominated by felsic terrigenous materials. The results provide further evidences for that the granite and geneiss of the Yinshan Oldland might be the source of sediment of the coal from the Datong coalfield.

Dai et al. indicated that Eu anomalies normally originate from the source region [68]. The felsic and felsic-intermediate detrital materials could result in negative Eu anomalies in the coals, while positive $\mathrm{Eu}$ anomalies could result from high-temperature solutions and alkali mafic rocks from source region. Apart from coal sample WJW-10 $\left(\mathrm{Eu}_{\mathrm{N}} / \mathrm{Eu}_{\mathrm{N}}{ }^{*}=1.08\right)$ and parting sample WJW-11 $\left(\mathrm{Eu}_{\mathrm{N}} / \mathrm{Eu}_{\mathrm{N}}{ }^{*}=1.25\right)$, the values of $\mathrm{Eu}_{\mathrm{N}} / \mathrm{Eu}_{\mathrm{N}}{ }^{*}$ for all the remaining samples are lower than 1 (Table 4). Along with the ratio of $\mathrm{Al}_{2} \mathrm{O}_{3} / \mathrm{TiO}_{2}$, the results of the figure of $\mathrm{Zr} / \mathrm{TiO}_{2} \mathrm{vs}$. Nb/Y, and the enrichment of the lithophile elements in the No. 5 coal, it can be inferred that most samples probably have felsic detrital input. The weakly positive Eu anomalies of samples WJW-10 and WJW-11 are probably attributed to the high content of feldspar minerals in the granite from the source region [75]. The same situation (the majority of samples displaying negative Eu anomalies while only a few individual samples have positive Eu anomalies) has been found in the Hunchun coalfield [75], as well as in the Tongjialiang mine, Datong coalfield [36]. Both studies indicated that the feldspar of granite, especially plagioclase, is the main carrier of Eu. Previous studies by Jian et al. [85] and Zhao et al. [19] showed old granites from the Yinshan Oldland that have L-type REY enrichment and a weak positive Eu anomaly. All these evidences further support that the Yinshan Oldland is the potential source region of sediment of the Wujiawan coals.

Gadolinium anomalies in coal are mainly controlled by the source regions, seawater, hydrothermal solutions, etc. [68] The Wujiawan coals have a weakly positive Gd anomalies (with a mean of 1.10) (Table 5), and a previous investigation by Kevin and Zhou suggest that a positive Gd anomaly may evidence influence of cold acidic waters [86]. However, relative high sulfur content in sample WJW-10 along with the cell-filling calcites (see Figure 4c), fracture-filling calcites (see Figure 4d), and the pyrite co-occurring with calcite (see Figure 4e), as well as H-type REY enrichment of most the coal samples suggest that the No. 5 coal may be influenced by alkaline waters (seawater or derivatives) rather than a cold acidic water contribution. All these were further supported by the marine-terrigenous depositional environment of C-P coal from Datong coalfield.

\subsection{Modes of Occurrence of Enriched Valuable Elements}

Figure 9 shows the concentration variations between ash yield and enriched elements ( $\mathrm{Li}, \mathrm{Ga}$, and HFSEs) in the No. 5 coals from the Wujiawan mine. All the enriched elements exhibit similar changes, consistent with the variation of ash yield. However, because the REY in the No. 5 coal probably have both organic and inorganic affinities, they do not show a similar fluctuation associated with the ash yield in the profile. The source of REY in the No. 5 coal will be discussed separately with other enriched elements. 


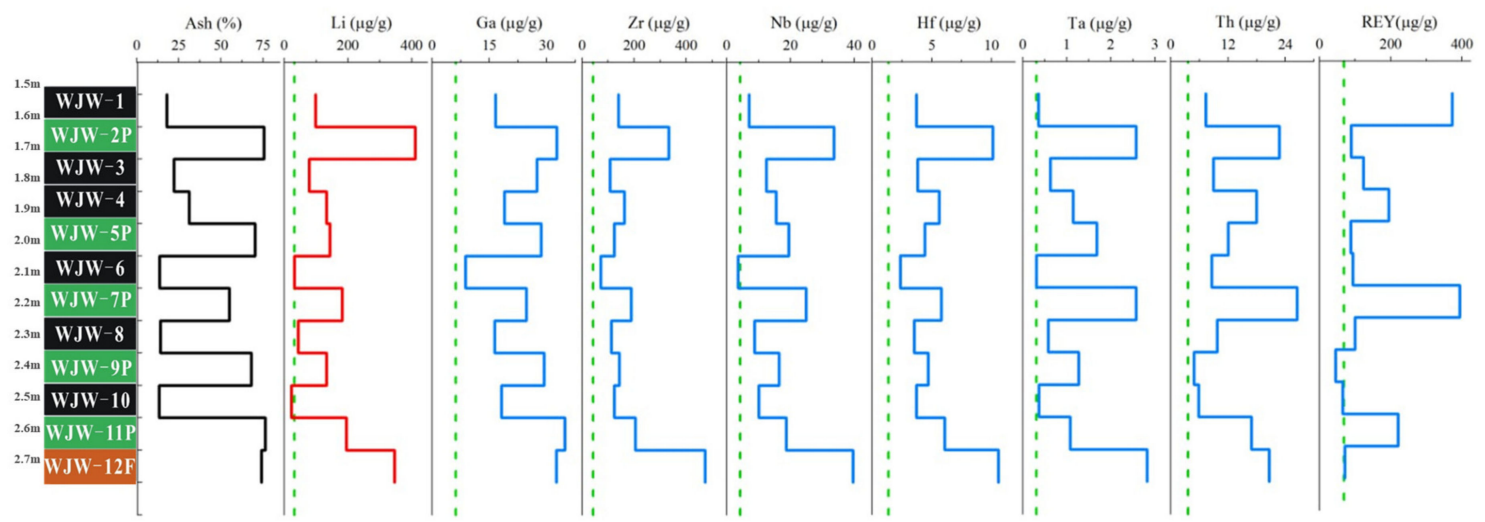

Figure 9. Concentration variations of ash yield and enriched elements ( $\mathrm{Li}, \mathrm{Ga}, \mathrm{Zr}, \mathrm{Nb}, \mathrm{Hf}, \mathrm{Ta}, \mathrm{Th}$, and REY) in the No. 5 Coals from the Wujiawan mine. The green dotted lines represent the average value of each element for world hard coals [65].

\subsubsection{Lithium}

The content of $\mathrm{Li}$ in the No. 5 coal ranged from 22.7 to $411.6 \mu \mathrm{g} / \mathrm{g}$ (Table 3 ), with a mean concentration of $67.66 \mu \mathrm{g} / \mathrm{g}$, which is around seven times higher compared to world hard coals (see Figure 5) [65]. Furthermore, the concentration of $\mathrm{Li}$ in the partings is higher than in the coal samples, with an average of $234.88 \mu \mathrm{g} / \mathrm{g}$, which is around 5 times higher than the value in world clays [66].

Due to the potential economic value, the issue of investigating the mode of occurrence of Li has become an urgent topic worldwide. Earlier studies have suggested that Li can occur both in inorganic and organic matter in coals $[9,32,33,87]$, while other studies on the coals from the Jungar Basin indicated that $\mathrm{Li}$ is mainly associated with kaolinite/illite, chlorite, and boehmite [22,71,84]. However, Li mainly occurs in aluminosilicate minerals, such as kaolinite, in the coal from the Datong coalfield and Ningwu coalfield (adjacent to the Datong coalfield) [15,29]. In this study, the strong affinity of Li and ash yield $(r=0.80)$, along with a similar variation between $\mathrm{Li}$ and ash yield (see Figure 9) through the seam section, indicate an inorganic affinity of the $\mathrm{Li}$ in the No. 5 coal. Lithium also has strong correlation with $\mathrm{SiO}_{2}$ (0.82), $\mathrm{Al}_{2} \mathrm{O}_{3}(0.78)$, and the lithophile elements, including $\mathrm{Li}-\mathrm{Zr}(0.90), \mathrm{Li}-\mathrm{Nb}(0.93), \mathrm{Li}-\mathrm{Hf}$ (0.97), Li-Ta (0.87), and Li-Bi (0.82) (Table 5 and see Figure 10a-e), suggesting that aluminosilicate minerals probably are the main carrier of Li. The frequently observed clay minerals under the optical microscopy, XRD, and SEM-EDS provide further evidence that kaolinite (see Figures 3 and 4a,b) might be the main Li-carrier mineral in this coal. This is consistent with the results from the No. 5 coal from the Yanzishan mine, Datong coalfield, which is adjacent to the Wujiawan mine [29]. The high content of $\mathrm{Li}$ and strong correlations between $\mathrm{Li}$ and lithophile elements also reveal that the $\mathrm{Li}$ in the Wujiawan coal originates from the source region-Yinshan Oldland. 

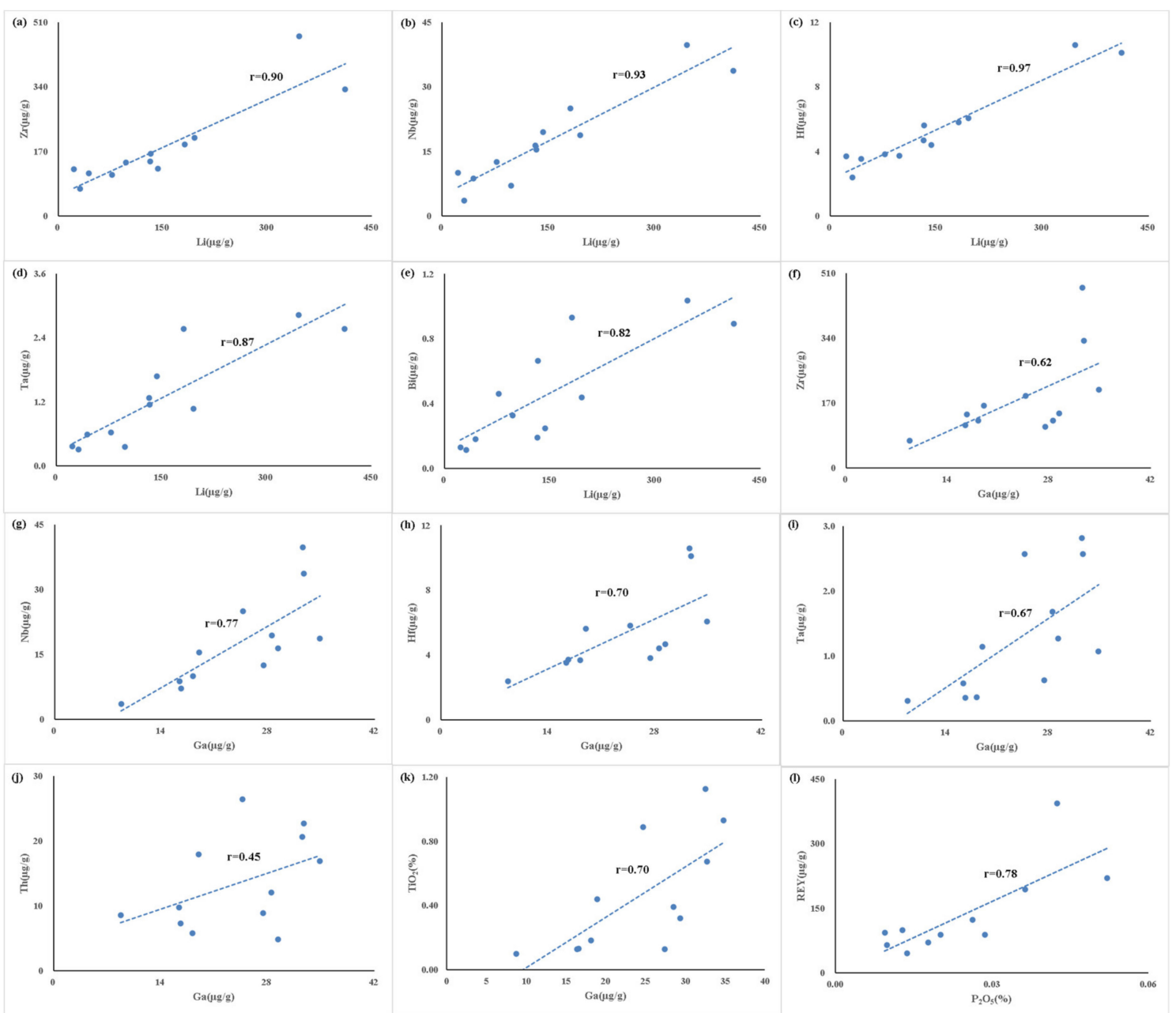

Figure 10. Correlation of: (a), $\mathrm{Zr}$ to $\mathrm{Li} ;(\mathbf{b}), \mathrm{Nb}$ to Li; (c), $\mathrm{Hf}$ to $\mathrm{Li} ;(\mathrm{d}), \mathrm{Ta}$ and $\mathrm{Li} ;(\mathbf{e}), \mathrm{Bi}$ to $\mathrm{Li} ;(\mathbf{f}), \mathrm{Zr}$ to $\mathrm{Ga} ;(\mathbf{g}), \mathrm{Nb}$ to $\mathrm{Ga} ;(\mathbf{h}), \mathrm{Hf}$ to $\mathrm{Ga} ;(\mathbf{i}), \mathrm{Ta}$ to $\mathrm{Ga} ;(\mathbf{j})$, Th to $\mathrm{Ga} ;(\mathbf{k}), \mathrm{TiO}_{2}$ to $\mathrm{Ga}$; and (1), $\mathrm{REY}$ to $\mathrm{P}_{2} \mathrm{O}_{5}$.

\subsubsection{Gallium}

The content of Ga in the Wujiawan coal samples ranges from 8.7 to $27.4 \mu \mathrm{g} / \mathrm{g}$ and varies from 24.7 to $34.8 \mu \mathrm{g} / \mathrm{g}$ in the parting samples, with mean concentrations of $17.72 \mu \mathrm{g} / \mathrm{g}$ and $30.02 \mu \mathrm{g} / \mathrm{g}$ (Table 3), respectively. The average Ga content in the coal samples is around three times higher than the average Ga content in world bituminous coals $(5.8 \mu \mathrm{g} / \mathrm{g})$ [65], while the mean concentration of Ga is around two times higher compared to the average content of Ga in the world clays $(16 \mu \mathrm{g} / \mathrm{g})$ [66].

Gallium is a valuable and rare metal in coal. Ga generally has a strong affinity with the clay minerals in coal, such as kaolinite and illite $[10,21,88,89]$. However, Ga can also associate with other minerals, including sulfide minerals [88], goyazite [22], and svanbergite [71], etc. and organic matters [67]. In the present study, it can be inferred that inorganic matter is the main carrier of $\mathrm{Ga}$, owing to its strong positive affinity with ash yield ( $\mathrm{r}=0.88$, see Figure $7 \mathrm{~b})$. In addition, the Ga in the No. 5 coal has strong and similar correlations with $\mathrm{Al}_{2} \mathrm{O}_{3}$ and $\mathrm{SiO}_{2}(\mathrm{r}=0.88$ and 0.87 , respectively) (Table 5), suggesting that the Ga in the Wujiawan coal mainly associate with aluminosilicate minerals (e.g., kaolinite). Furthermore, Ga is highly related to Ti (0.70) (see Figure 10k and Table 5), implying that Ga also occurs in the Ti-bearing minerals, as discussed above, Ti-bearing kaolinite may be also the carrier of Ga. A previous study by Liu et al. suggesting that aluminosilicate minerals are the main Ga carrier in the coal from Ningwu coalfield (which is adjacent to Datong coalfield) provides further support for the results [15]. The similar variation between $\mathrm{Ga}$ and $\mathrm{Li}$, along with the high affinity between Ga and Zr, Ga and Nb, Ga and Hf, Ga and Ta, and Ga and Th (see Figure 10f-j) indicate 
that Ga has the same origin as these elements and may originate from the granite and gneiss of the Yinshan Oldland.

\subsubsection{Zirconium, Niobium, Hafnium, Tantalum, and Thorium}

Zirconium, $\mathrm{Nb}, \mathrm{Hf}, \mathrm{Ta}$, and $\mathrm{Th}$ are regarded as HFSEs and have been found enriched in the coals from the southwest of China, such as Chongqing [90] and Yunnan [91]. An earlier study has also revealed that HFSEs have a higher content in the coals from the Daqingshan coalfield in North China than in world hard coals [19]. Furthermore, these studies suggested that most of the HFSEs occur as absorbed ions in the clay minerals in coal. However, the organic matter can also be the carrier of HFSEs $[5,22]$.

The average content of $\mathrm{Zr}, \mathrm{Nb}, \mathrm{Hf}, \mathrm{Ta}$, and $\mathrm{Th}$ in the No. 5 coal samples are 119.8, 9.6, 3.8, 0.6, and $9.7 \mu \mathrm{g} / \mathrm{g}$, respectively. The average concentration of all HFSEs is more than two times higher compared to the mean content in world hard coals. Interestingly, the HFSEs content in the samples WJW-3 and WJW-4 (both are coal samples), which are interlayered between the parting samples WJW-2P and WJW-5P, is higher than the other coal bench samples. This may be due to the influence of groundwater when HFSEs got leached from the adjacent parting and became incorporated into the organic matter [22].

The strong correlation coefficients between HFSEs (Table 5), along with the similar variation between these elements (see Figure 9), indicate that the HFSEs probably have similar modes of occurrence. Figure $7 \mathrm{~b}$ shows that HFSEs in the No. 5 coal have high correlation coefficients with ash, and this, together with highly positive correlation coefficients between HFSEs and $\mathrm{Al}_{2} \mathrm{O}_{3}\left(\mathrm{SiO}_{2}\right)(\mathrm{Table} 5)$, indicates that aluminosilicate minerals are the HFSEs-carrier minerals. Furthermore, the HFSEs in the No. 5 coal also have strong affinity with $\mathrm{TiO}_{2}$ (Table 5), which probably suggests that the Ti-bearing clay minerals are also possible carriers for HFSEs. Considering the high correlation coefficients of $\mathrm{Li}, \mathrm{Ga}$, and HFSEs, it appears that the HFSEs also originated from the granite and gneiss of the Yinshan Oldland.

\subsubsection{REY}

Numerous investigations have suggested that REY in coal generally have a strong affinity with the ash yield and are generally associated with minerals $[5,17,21,87,92]$, including clay minerals, phosphates, and, to a lesser extent, associated with the organic compounds in coal $[4,10,21,93]$. In the present study, the weak negative correlations between REY and ash (see Figure 7b) $(r=-0.096)$, REY and $\mathrm{Al}_{2} \mathrm{O}_{3}(\mathrm{r}=-0.095)$, and $\mathrm{REY}$ and $\mathrm{SiO}_{2}(\mathrm{r}=-0.075)$ (Table 5) suggest that $\mathrm{REY}$ have association with either organic or inorganic matter in the Wujiawan coal. However, REY show a strong affinity with $\mathrm{P}_{2} \mathrm{O}_{5}\left(0.78\right.$, see Figure 10), along with the weakly negative affinity between $\mathrm{P}_{2} \mathrm{O}_{5}$ and ash (see Figure $7 \mathrm{~b}$ ), which suggests that REY probably associate with organophosphates. This is supported by no P-bearing mineral being detected in the Wujiawan coal. Although the phosphorus in coal normally occurs as inorganic mineral components [94], the possibility of the presence of organic phosphorus compounds has been noted by Swaine [95].

\subsection{Evaluation of Li in the Wujiawan Coals and Comparison with Adjacent Coals in the Datong Coalfield}

The No. 5 coal from the Wujiawan mine is a type of coal, with several enriched valuable elements, such as Li, Ga, HFSEs, and REY (Table 3, see Figure 4). In particular, the content of Li is around seven times higher when compared to the mean concentration of $\mathrm{Li}$ in world hard coals. Earlier studies on the concentrations of $\mathrm{Li}$ in coals from different coal mines of Datong coalfield have been discussed in detail $[29,35,36,39,96,97]$. The content of $\mathrm{Li}$ in the Datong coalfield ranges from 13.3 to $294.6 \mu \mathrm{g} / \mathrm{g}$, with a mean of $84.6 \mu \mathrm{g} / \mathrm{g}$. Figure 11 shows that the Li content in coals is relatively high in the north Datong coalfield, which may be due to the area being closer to the source region, while the high Li-content area in the south Datong coalfield may be due to the influence of seawater [11]. As Sun et al. [98] reported, the minimum mineable grade for $\mathrm{Li}$ in Chinese coal should be set at $120 \mu \mathrm{g} / \mathrm{g}$. The content of $\mathrm{Li}$ in the 
No. 5 coal from the Wujiawan mine $(67.66 \mu \mathrm{g} / \mathrm{g})$ does not reach this level; however, in the northern and eastern part of the Datong coalfield there are several regions where the Li content is higher than the mineable grade. For example, in the northern Datong coalfield, there is a mine with the Li content of $294.6 \mu \mathrm{g} / \mathrm{g}$ (see Figure 11). This is significantly higher than the mineable grade; therefore, there is the potential for economically viable recovery of $\mathrm{Li}$ in these parts of the Datong coalfield. Furthermore, because of the strong affinity with kaolinite, Li in Wujiawan coal can be further enriched in byproducts of coals since $\mathrm{Li}$ is not considered to be the volatile element $[99,100]$. Thus, the coal ash, including the fly and bottom ash, should be regarded as an economically viable source for Li recovery. Considering that the coal consumption in China will continue to grow due to its rapid economic development, if the Li in all these coals occurs in inorganic associations, or partly occurs in inorganic associations, then it should be beneficial to pay more attention to the utilization process. Thus, there would be significant economic value in the recycling and utilization of Li in the fly ash of coal from the Datong coalfield, especially from the northern region of the Datong coalfield.

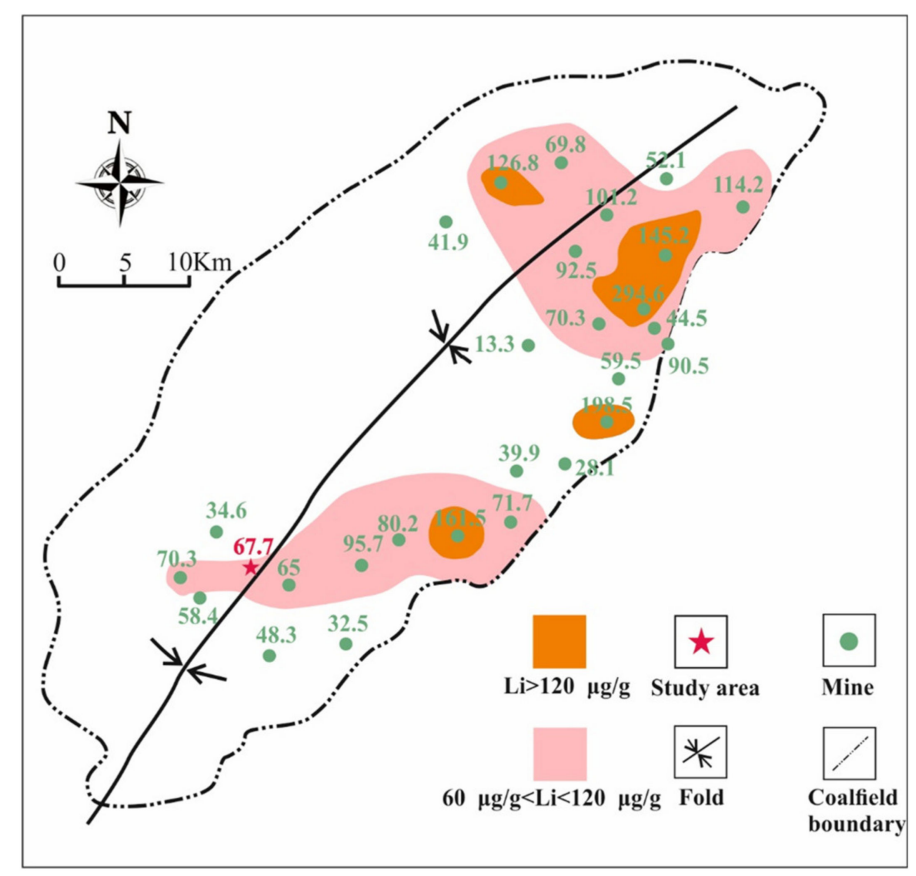

Figure 11. Content map of lithium in the Datong coalfield (the green number represents the concentration of Li ( $\mu \mathrm{g} / \mathrm{g})$, data from Yuan et al. [29,35,36], Liu et al. [39], Ma [96], and Shao [97].

\section{Conclusions}

The Wujiawan coal is a kind of low-ash, medium-high-volatile, low moisture, medium-sulfur, bituminous coal. The main mineralogical compositions of Wujiawan coals are primarily characterized by kaolinite, calcite, and pyrite, along with a small amount of quartz and illite. $\mathrm{The}^{\mathrm{SiO}} \mathrm{O}_{2} / \mathrm{Al}_{2} \mathrm{O}_{3}$ ratio of the No. 5 coal is very close to the value of theoretical kaolinite; this is due to the low content of quartz in the No. 5 coal seam and Si mainly occur in kaolinite. In addition, the Wujiawan coals are slightly enriched in $\mathrm{P}_{2} \mathrm{O}_{5}\left(\mathrm{TiO}_{2}, \mathrm{Fe}_{2} \mathrm{O}_{3}, \mathrm{MgO}, \mathrm{K}_{2} \mathrm{O}\right.$, and $\left.\mathrm{Na}_{2} \mathrm{O}\right)$ have values lower than the corresponding average values in Chinese coals.

The Wujiawan coals are enriched in Li, Ga, HFSEs, and REY; this is particularly true for the case of $\mathrm{Li}$ (average concentration of $67.66 \mu \mathrm{g} / \mathrm{g}$ ), which is around 7 times higher compared to world hard coals. Lithium, Ga, Zr, Nb, Hf, Ta, and Th have strong inorganic affinities, whereas REY have organic affinities. The main carriers of Li, Ga, and HFSEs are aluminosilicate minerals, while REY probably associate with organophosphates. The HFSEs are enriched in both partings and the adjacent coal samples, suggesting that the partings were subjected to leaching during the diagenesis. The distribution 
patterns of REY, along with the ratio of $\mathrm{Al}_{2} \mathrm{O}_{3} / \mathrm{TiO}_{2}$ and the figure of $\mathrm{Zr} / \mathrm{TiO}{ }_{2}$ versus $\mathrm{Nb} / \mathrm{Y}$, suggest that these elements in No. 5 coal originate mainly from the source region with felsic detrital materials. The Yinshan Oldland may be the potential source region of sediment of the Wujiawan coals. The mean content of $\mathrm{Li}$ in the Datong coalfield is $84.6 \mu \mathrm{g} / \mathrm{g}$. However, the Li content in several regions are higher than the mineable grade, moreover, in the northern Datong coalfield, there is a mine with the Li content of $294.6 \mu \mathrm{g} / \mathrm{g}$. This is significantly higher than the mineable grade; therefore, there is the potential for economic recovery of $\mathrm{Li}$ in these parts of Datong coalfield. Furthermore, $\mathrm{Li}$ in Wujiawan coal can be further enriched in byproducts of coals. It should, therefore, be important to pay more attention to the utilization process, since there would be a potential economic value for the recycling and utilization of $\mathrm{Li}$ in fly ash, in particular from the northern Datong coalfield.

Author Contributions: J.M.: Conceptualization, Writing-Original draft preparation. L.X.: Formal analysis, Data curation. K.Z.: Formal analysis, Data curation. Y.J.: Formal analysis, Data curation. Z.W.: Formal analysis, Data curation. J.L.: Formal analysis. W.G.: Writing-Reviewing and Editing, Supervision. P.G.: methodology. S.Q.: Data curation. C.Z.: Writing-Reviewing and Editing, Supervision. All authors have read and agreed to the published version of the manuscript.

Funding: This study was supported by the National Natural Science Foundation of China (No. 41872173) and Natural Science Foundation of Hebei Province (No. 2016402104).

Acknowledgments: Bangjun Liu is thanked for his constructive suggestions and language checking for this manuscript. The authors sincerely thank Brigitte Held from the GRADE of Goethe University for the assistance of language polishing.

Conflicts of Interest: The authors declare no conflict of interest.

\section{References}

1. BP Full Report_-BP Statistical Review of World Energy 2019; BP: London, UK, 2019.

2. Bai, X.; Ding, H.; Lian, J.; Ma, D.; Yang, X.; Sun, N.; Xue, W.; Chang, Y. Coal production in China: Past, present, and future projections. Int. Geol. Rev. 2018, 60, 535-547. [CrossRef]

3. Prachiti, P.K.; Manikyamba, C.; Singh, P.K.; Balaram, V.; Lakshminarayana, G.; Raju, K.; Singh, M.P.; Kalpana, M.S.; Arora, M. Geochemical systematics and precious metal content of the sedimentary horizons of Lower Gondwanas from the Sattupalli coal field, Godavari Valley, India. Int. J. Coal Geol. 2011, 88, 83-100. [CrossRef]

4. Seredin, V.; Dai, S. Coal deposits as potential alternative sources for lanthanides and yttrium. Int. J. Coal Geol. 2012, 94, 67-93. [CrossRef]

5. Wang, P.; Yan, X.; Guo, W.; Zhang, S.; Wang, Z.; Xu, Y.; Wang, L. Geochemistry of trace elements in coals from the yueliangtian mine, western guizhou, China: Abundances, modes of occurrence, and potential industrial utilization. Energy Fuels 2016, 30, 10268-10281. [CrossRef]

6. Zhao, F.; Cong, Z.; Sun, H.; Ren, D. The geochemistry of rare earth elements (REE) in acid mine drainage from the Sitai coal mine, Shanxi Province, North China. Int. J. Coal Geol. 2007, 70, 184-192. [CrossRef]

7. Dai, S.; Li, T.; Jiang, Y.; Ward, C.R.; Hower, J.C.; Sun, J.; Liu, J.; Song, H.; Wei, J.; Li, Q.; et al. Mineralogical and geochemical compositions of the Pennsylvanian coal in the Hailiushu Mine, Daqingshan Coalfield, Inner Mongolia, China: Implications of sediment-source region and acid hydrothermal solutions. Int. J. Coal Geol. 2015, 137, 92-110. [CrossRef]

8. Dai, S.; Zou, J.; Jiang, Y.; Ward, C.R.; Wang, X.; Li, T.; Xue, W.; Liu, S.; Tian, H.; Sun, X.; et al. Mineralogical and geochemical compositions of the Pennsylvanian coal in the Adaohai Mine, Daqingshan Coalfield, Inner Mongolia, China: Modes of occurrence and origin of diaspore, gorceixite, and ammonian illite. Int. J. Coal Geol. 2012, 94, 250-270. [CrossRef]

9. Sun, Y.; Zhao, C.; Li, Y.; Wang, J.; Zhang, J.; Jin, Z.; Lin, M.; Wolfgang, K. Further Information of the Associated Li Deposits in the No.6 Coal Seam at Jungar Coalfield, Inner Mongolia, Northern China. Acta Geol. Sin. Engl. Ed. 2013, 87, 1097-1108. [CrossRef]

10. Dai, S.; Li, D.; Chou, C.L.; Zhao, L.; Zhang, Y.; Ren, D.; Ma, Y.; Sun, Y. Mineralogy and geochemistry of boehmite-rich coals: New insights from the Haerwusu Surface Mine, Jungar Coalfield, Inner Mongolia, China. Int. J. Coal Geol. 2008, 74, 185-202. [CrossRef] 
11. Wang, W.; Qin, Y.; Sang, S.; Zhu, Y.; Wang, C.; Weiss, D.J. Geochemistry of rare earth elements in a marine influenced coal and its organic solvent extracts from the Antaibao mining district, Shanxi, China. Int. J. Coal Geol. 2008, 76, 309-317. [CrossRef]

12. Dai, S.; Ren, D.; Chou, C.L.; Li, S.; Jiang, Y. Mineralogy and geochemistry of the No. 6 Coal (Pennsylvanian) in the Junger Coalfield, Ordos Basin, China. Int. J. Coal Geol. 2006, 66, 253-270. [CrossRef]

13. Dai, S.; Ren, D. Effects of magmatic intrusion on mineralogy and geochemistry of coals from the Fengfeng-Handan coalfield, Hebei, China. Energy Fuels 2007, 21, 1663-1673. [CrossRef]

14. Bai, X.; Li, W.; Wang, Y.; Ding, H. The distribution and occurrence of mercury in Chinese coals. Int. J. Coal Sci. Technol. 2017, 4, 172-182. [CrossRef]

15. Liu, B.; Wang, J.; He, H.; Mishra, V.; Li, Y.; Wang, J.; Zhao, C. Geochemistry of Carboniferous coals from the Laoyaogou mine, Ningwu coalfield, Shanxi Province, northern China: Emphasis on the enrichment of valuable elements. Fuel 2020, 279, 118414. [CrossRef]

16. Dai, S.; Ren, D.; Li, S. Discovery of the superlarge gallium ore deposit in Jungar, Inner Mongolia, North China. Chinese Sci. Bull. 2006, 51, 2243-2252. [CrossRef]

17. Sun, Y.; Zhao, C.; Qin, S.; Xiao, L.; Li, Z.; Lin, M. Occurrence of some valuable elements in the unique "high-aluminium coals" from the Jungar coalfield, China. Ore Geol. Rev. 2016, 72, 659-668. [CrossRef]

18. Xu, J.; Sun, Y.; Kalkreuth, W. Characteristics of Trace Elements of the No. 6 Coal in the Guanbanwusu Mine, Junger Coalfield, Inner Mongolia. Energy Explor. Exploit. 2011, 29, 827-841. [CrossRef]

19. Zhao, L.; Dai, S.; Nechaev, V.P.; Nechaeva, E.V.; Graham, I.T.; French, D.; Sun, J. Enrichment of critical elements (Nb-Ta-Zr-Hf-REE) within coal and host rocks from the Datanhao mine, Daqingshan Coalfield, northern China. Ore Geol. Rev. 2019, 111, 102951. [CrossRef]

20. Wang, W.; Qin, Y.; Lu, X.; Zhao, J.; Wang, J.; Wu, G.; Liu, J. Distribution, occurrence and enrichment causes of gallium in coals from the Jungar Coalfield, Inner Mongolia. Sci. China Earth Sci. 2011, 54, 1053-1068. [CrossRef]

21. Zhao, C.; Liu, B.; Xiao, L.; Li, Y.; Liu, S.; Li, Z.; Zhao, B.; Ma, J.; Chu, G.; Gao, P.; et al. Significant enrichment of $\mathrm{Ga}, \mathrm{Rb}, \mathrm{Cs}$, REEs and $\mathrm{Y}$ in the Jurassic No. 6 coal in the Iqe Coalfield, northern Qaidam Basin, China-A hidden gem. Ore Geol. Rev. 2017, 83, 1-13. [CrossRef]

22. Dai, S.; Jiang, Y.; Ward, C.R.; Gu, L.; Seredin, V.V.; Liu, H.; Zhou, D.; Wang, X.; Sun, Y.; Zou, J.; et al. Mineralogical and geochemical compositions of the coal in the Guanbanwusu Mine, Inner Mongolia, China: Further evidence for the existence of an $\mathrm{Al}$ (Ga and REE) ore deposit in the Jungar Coalfield. Int. J. Coal Geol. 2012, 98, 10-40. [CrossRef]

23. Dai, S.; Liu, J.; Ward, C.R.; Hower, J.C.; French, D.; Jia, S.; Hood, M.M.; Garrison, T.M. Mineralogical and geochemical compositions of Late Permian coals and host rocks from the Guxu Coalfield, Sichuan Province, China, with emphasis on enrichment of rare metals. Int. J. Coal Geol. 2016, 166, 71-95. [CrossRef]

24. Dai, S.; Yan, X.; Ward, C.R.; Hower, J.C.; Zhao, L.; Wang, X.; Zhao, L.; Ren, D.; Finkelman, R.B. Valuable elements in Chinese coals: A review. Int. Geol. Rev. 2018, 60, 590-620. [CrossRef]

25. Dai, S.; Finkelman, R.B. Coal as a promising source of critical elements: Progress and future prospects. Int. J. Coal Geol. 2018, 186, 155-164. [CrossRef]

26. Dai, S.; Zhao, L.; Peng, S.; Chou, C.L.; Wang, X.; Zhang, Y.; Li, D.; Sun, Y. Abundances and distribution of minerals and elements in high-alumina coal fly ash from the Jungar Power Plant, Inner Mongolia, China. Int. J. Coal Geol. 2010, 81, 320-332. [CrossRef]

27. Chu, G.; Xiao, L.; Jin, Z.; Lin, M.; Blokhin, M.G. The Relationship between Trace Element Concentrations and Coal-Forming Environments in the No. 6 Coal Seam, Haerwusu Mine, China. Energy Explor. Exploit. 2015, 33, 91-104. [CrossRef]

28. Xiao, L.; Zhao, B.; Duan, P.; Shi, Z.; Ma, J.; Lin, M. Geochemical Characteristics of Trace Elements in the No. 6 Coal Seam from the Chuancaogedan Mine, Jungar Coalfield, Inner Mongolia, China. Minerals 2016, 6, 28. [CrossRef]

29. Yuan, Y.; Tang, S.; Zhang, S. Concentrations and modes of occurrence of some potentially valuable and toxic elements in the No. 5 coal from the Yanzishan Mine, Datong Coalfield, Shanxi Province, China. Energy Explor. Exploit. 2019, 37, 1694-1720. [CrossRef]

30. Dai, S.; Wang, X.; Seredin, V.V.; Hower, J.C.; Ward, C.R.; O’Keefe, J.M.K.; Huang, W.; Li, T.; Li, X.; Liu, H.; et al. Petrology, mineralogy, and geochemistry of the Ge-rich coal from the Wulantuga Ge ore deposit, Inner Mongolia, China: New data and genetic implications. Int. J. Coal Geol. 2012, 90-91, 72-99. [CrossRef] 
31. Dai, S.; Seredin, V.V.; Ward, C.R.; Jiang, J.; Hower, J.C.; Song, X.; Jiang, Y.; Wang, X.; Gornostaeva, T.; $\mathrm{Li}, \mathrm{X}$; ; et al. Composition and modes of occurrence of minerals and elements in coal combustion products derived from high-Ge coals. Int. J. Coal Geol. 2014, 121, 79-97. [CrossRef]

32. Finkelman, R.B. Modes of Occurrence of Trace Elements and Minerals in Coal: An Analytical Approach. In Atomic and Nuclear Methods in Fossil Energy Research; Springer US: Boston, MA, USA, 1982; pp. 141-149.

33. Sun, Y.; Zhao, C.; Zhang, J.; Yang, J.; Zhang, Y.; Yuan, Y.; Xu, J.; Duan, D. Concentrations of Valuable Elements of the Coals from the Pingshuo Mining District, Ningwu Coalfield, Northern China. Energy Explor. Exploit. 2013, 31, 727-744. [CrossRef]

34. Qin, S.; Lu, Q.; Li, Y.; Wang, J.; Zhao, Q.; Gao, K. Relationships between trace elements and organic matter in coals. J. Geochemical Explor. 2018, 188, 101-110. [CrossRef]

35. Yuan, Y.; Tang, S.; Zhang, S.; Yang, N. Mineralogical and geochemical characteristics of trace elements in the Yongdingzhuang Mine, Datong Coalfield, Shanxi province, China. Minerals 2018, 8. [CrossRef]

36. Yuan, Y.; Tang, S.; Zhang, S. Geochemical and mineralogical characteristics of the middle Jurassic coals from the tongjialiang mine in the northern Datong Coalfield, Shanxi province, China. Minerals 2019, 9. [CrossRef]

37. Ma, J.; Liu, B.; Zhang, K.; Wang, Z.; Li, J.; Blokhin, M.G.; Zhao, C. Geochemical characteristics of No. 6 coal from Nanyangpo Mine, Datong coalfield, north China: Emphasis on the influence of hydrothermal solutions. Energy Explor. Exploit. 2020. [CrossRef]

38. Wang, J.; Wang, Q.; Tian, L. Characteristics of trace elements of the No. 9 coal seam from the Anjialing Mine, Ningwu coalfield, China. Chinese J. Geochem. 2015, 34, 391-400. [CrossRef]

39. Liu, D.; Zhao, F.; Zhou, A.; Ma, M.; Wen, X. The geochemistry of trace elements in the No.2 coal seam of Qifengshan coalmine at Datong coalfield. J. China Coal Soc. 2013, 38, 637-643.

40. Zhao, G.; Cawood, P.A.; Wilde, S.A.; Sun, M. Review of global 2.1-1.8 Ga orogens: Implications for a pre-Rodinia supercontinent. Earth-Science Rev. 2002, 59, 125-162. [CrossRef]

41. GB/T 2008. 482: 2008 Sampling of Coal Seams [in Chinese]; National Coal Standardization Technical Committee: Beijing, China, 2008.

42. ASTM D3173-11 Standard Test Method for Moisture in the Analysis Sample of Coal and Coke; ASTM International: West Conshohocken, PA, USA, 2011; p. 202.

43. ASTM D3174-11 Standards Test Method for Ash in the Analysis Sample of Coal and Coke; ASTM International: West Conshohocken, PA, USA, 2011.

44. ASTM D3175-11 Standard Test Method for Volatile Matter in the Analysis Sample of Coal and Coke; ASTM International: West Conshohocken, PA, USA, 2011.

45. ASTM D3177-02(2007) Standard Test Methods for Total Sulfur in the Analysis Sample of Coal and Coke; ASTM International: West Conshohocken, PA, USA, 2012.

46. ASTM D2798-05 Standard Test Method for Microscopical Determination of the Vitrinite Reflectance of Coal; ASTM International: West Conshohocken, PA, USA, 2011.

47. China Coal Science Research Institute. GB/T 15224.1-2010 Classification for Quality of Coal-Part 1: Ash [in Chinese]; National Coal Standardization Technical Committee: Beijing, China, 2010.

48. China Coal Research Institute. MT/T 849-2000 Classification for Volatile Matter of Coal [in Chinese]; National Coal Standardization Technical Committee: Beijing, China, 2000.

49. China Coal Research Institute. MT/T 850-2000 CClassification for Total Moisture in Coal [in Chinese]; National Coal Standardization Technical Committee: Beijing, China, 2000.

50. China Coal Science Research Institute. GB/T 15224.2-2010 Classification for Quality of Coal_Part 2: Sulfur content [in Chinese]; National Coal Standardization Technical Committee: Beijing, China, 2010.

51. Permana, A.K.; Ward, C.R.; Li, Z.; Gurba, L.W. Distribution and origin of minerals in high-rank coals of the South Walker Creek area, Bowen Basin, Australia. Int. J. Coal Geol. 2013, 116-117, 185-207. [CrossRef]

52. Ward, C.R. Analysis, origin and significance of mineral matter in coal: An updated review. Int. J. Coal Geol. 2016, 165, 1-27. [CrossRef]

53. Wang, X.; Zhang, L.; Jiang, Y.; Wei, J.; Chen, Z. Mineralogical and Geochemical Characteristics of the Early Permian Upper No. 3 Coal from Southwestern Shandong, China. Minerals 2016, 6, 58. [CrossRef]

54. Rajak, P.K.; Singh, V.K.; Singh, A.L.; Kumar, N.; Kumar, O.P.; Singh, V.; Kumar, A.; Rai, A.; Rai, S.; Naik, A.S.; et al. Study of minerals and selected environmentally sensitive elements in Kapurdi lignites of Barmer Basin, Rajasthan, western India: Implications to environment. Geosci. J. 2019, 24, 441-458. [CrossRef] 
55. Rajak, P.K.; Singh, V.K.; Singh, P.K.; Singh, A.L.; Kumar, N.; Kumar, O.P.; Singh, V.; Kumar, A. Geochemical implications of minerals and environmentally sensitive elements of Giral lignite, Barmer Basin, Rajasthan (India). Environ. Earth Sci. 2018, 77, 698. [CrossRef]

56. Wang, P.; Ji, D.; Yang, Y.; Zhao, L. Mineralogical compositions of Late Permian coals from the Yueliangtian mine, western Guizhou, China: Comparison to coals from eastern Yunnan, with an emphasis on the origin of the minerals. Fuel 2016, 181, 859-869. [CrossRef]

57. Zhao, L.; Ward, C.R.; French, D.; Graham, I.T. Mineralogical composition of Late Permian coal seams in the Songzao Coalfield, southwestern China. Int. J. Coal Geol. 2013, 116-117, 208-226. [CrossRef]

58. Kortenski, J. Carbonate minerals in Bulgarian coals with different degrees of coalification. Int. J. Coal Geol. 1992, 20, 225-242. [CrossRef]

59. Dai, S.; Chou, C.-L.; Yue, M.; Luo, K.; Ren, D. Mineralogy and geochemistry of a Late Permian coal in the Dafang Coalfield, Guizhou, China: Influence from siliceous and iron-rich calcic hydrothermal fluids. Int. J. Coal Geol. 2005, 61, 241-258. [CrossRef]

60. Guo, W.; Li, J.; Wang, Z.; Zhang, K.; Gao, Z.; Ma, J.; Zhao, C. Mineralogical Characteristics of Early Permian Paragonite-Bearing Coal (No. 3) in the Jinyuan Mine, Tengxian Coalfield, Shandong Province, Eastern China. Minerals 2020, 10, 714. [CrossRef]

61. Chou, C.L. Sulfur in coals: A review of geochemistry and origins. Int. J. Coal Geol. 2012, 100, 1-13. [CrossRef]

62. Ward, C.R. Analysis and significance of mineral matter in coal seams. Int. J. Coal Geol. 2002, 50, $135-168$. [CrossRef]

63. Raes, F.; Van Dingenen, R.; Vignati, E.; Wilson, J.; Putaud, J.P.; Seinfeld, J.H.; Adams, P. Formation and cycling of aerosols in the global troposphere. Atmos. Environ. 2000, 34, 4215-4240. [CrossRef]

64. Dai, S.; Ren, D.; Chou, C.L.; Finkelman, R.B.; Seredin, V.V.; Zhou, Y. Geochemistry of trace elements in Chinese coals: A review of abundances, genetic types, impacts on human health, and industrial utilization. Int. J. Coal Geol. 2012, 94, 3-21. [CrossRef]

65. Ketris, M.P.; Yudovich, Y.E. Estimations of Clarkes for Carbonaceous biolithes: World averages for trace element contents in black shales and coals. Int. J. Coal Geol. 2009, 78, 135-148. [CrossRef]

66. Yaroshevsky, A.A. Abundances of chemical elements in the Earth's crust. Geochemistry Int. 2006, 44, 48-55. [CrossRef]

67. Seredin, V.V.; Dai, S.; Sun, Y.; Chekryzhov, I.Y. Coal deposits as promising sources of rare metals for alternative power and energy-efficient technologies. Appl. Geochem. 2013, 31, 1-11. [CrossRef]

68. Dai, S.; Graham, I.T.; Ward, C.R. A review of anomalous rare earth elements and yttrium in coal. Int. J. Coal Geol. 2016, 159, 82-95. [CrossRef]

69. Eskenazy, G.M. Trace elements geochemistry of the Dobrudza coal basin, Bulgaria. Int. J. Coal Geol. 2009, 78, 192-200. [CrossRef]

70. Eskanazy, G.; Finkelman, R.B.; Chattarjee, S. Some considerations concerning the use of correlation coefficients and cluster analysis in interpreting coal geochemistry data. Int. J. Coal Geol. 2010, 83, 491-493. [CrossRef]

71. Li, J.; Zhuang, X.; Yuan, W.; Liu, B.; Querol, X.; Font, O.; Moreno, N.; Li, J.; Gang, T.; Liang, G. Mineral composition and geochemical characteristics of the Li-Ga-rich coals in the Buertaohai-Tianjiashipan mining district, Jungar Coalfield, Inner Mongolia. Int. J. Coal Geol. 2016, 167, 157-175. [CrossRef]

72. Spears, D.A.; Zheng, Y. Geochemistry and origin of elements in some UK coals. Int. J. Coal Geol. 1999, 38, 161-179. [CrossRef]

73. Wang, J.; Yamada, O.; Nakazato, T.; Zhang, Z.G.; Suzuki, Y.; Sakanishi, K. Statistical analysis of the concentrations of trace elements in a wide diversity of coals and its implications for understanding elemental modes of occurrence. Fuel 2008, 87, 2211-2222. [CrossRef]

74. Xu, N.; Finkelman, R.B.; Xu, C.; Dai, S. What do coal geochemistry statistics really mean? Fuel 2020, 267,117084. [CrossRef]

75. Dai, S.; Guo, W.; Nechaev, V.P.; French, D.; Ward, C.R.; Spiro, B.F.; Finkelman, R.B. Modes of occurrence and origin of mineral matter in the Palaeogene coal (No. 19-2) from the Hunchun Coalfield, Jilin Province, China. Int. J. Coal Geol. 2018, 189, 94-110. [CrossRef]

76. Hower, J.; Eble, C.; O’Keefe, J.; Dai, S.; Wang, P.; Xie, P.; Liu, J.; Ward, C.; French, D. Petrology, Palynology, and Geochemistry of Gray Hawk Coal (Early Pennsylvanian, Langsettian) in Eastern Kentucky, USA. Minerals 2015, 5, 592-622. [CrossRef] 
77. Guo, W.; Dai, S.; Nechaev, V.P.; Nechaeva, E.V.; Wei, G.; Finkelman, R.B.; Spiro, B.F. Geochemistry of Palaeogene coals from the Fuqiang Mine, Hunchun Coalfield, northeastern China: Composition, provenance, and relation to the adjacent polymetallic deposits. J. Geochemical Explor. 2019, 196, 192-207. [CrossRef]

78. He, B.; Xu, Y.G.; Zhong, Y.T.; Guan, J.P. The Guadalupian-Lopingian boundary mudstones at Chaotian (SW China) are clastic rocks rather than acidic tuffs: Implication for a temporal coincidence between the end-Guadalupian mass extinction and the Emeishan volcanism. Lithos 2010, 119, 10-19. [CrossRef]

79. Hayashi, K.I.; Fujisawa, H.; Holland, H.D.; Ohmoto, H. Geochemistry of $\sim 1.9$ Ga sedimentary rocks from northeastern Labrador, Canada. Geochim. Cosmochim. Acta 1997, 61, 4115-4137. [CrossRef]

80. Winchester, J.A.; Floyd, P.A. Geochemical discrimination of different magma series and their differentiation products using immobile elements. Chem. Geol. 1977, 20, 325-343. [CrossRef]

81. Salters, V.J.M. Elements: High field strengthHigh field strength. In Geochemistry; Kluwer Academic Publishers: Dordrecht, The Netherlands, 2006; pp. 209-210.

82. Wang, J.; Wang, Q.; Shi, J.; Li, Z. Distribution and enrichment mode of Li in the No. 11 coal seam from Pingshuo mining district, Shanxi province. Energy Explor. Exploit. 2015, 33, 203-216. [CrossRef]

83. Yang, N.; Tang, S.-h.; Zhang, S.-h.; Xi, Z.-d.; Li, J.; Yuan, Y.; Guo, Y.-y. ying In seam variation of element-oxides and trace elements in coal from the eastern Ordos Basin, China. Int. J. Coal Geol. 2018, 197, 31-41. [CrossRef]

84. Sun, Y.; Zhao, C.; Li, Y.; Wang, J.; Liu, S. Li distribution and mode of occurrences in Li-bearing coal seam \#6 from the Guanbanwusu Mine, Inner Mongolia, northern China. Energy Explor. Exploit. 2012, 30. [CrossRef]

85. Jian, P.; Kröner, A.; Windley, B.F.; Zhang, Q.; Zhang, W.; Zhang, L. Episodic mantle melting-crustal reworking in the late neoarchean of the Northwestern North China Craton: Zircon ages of magmatic and metamorphic rocks from the Yinshan Block. Precambrian Res. 2012, 222-223, 230-254. [CrossRef]

86. Johannesson, K.H.; Zhou, X. Geochemistry of the rare earth elements in natural terrestrial waters: A review of what is currently known. Chinese J. Geochem. 1997, 16, 20-42. [CrossRef]

87. Qin, S.; Zhao, C.; Li, Y.; Zhang, Y. Review of coal as a promising source of lithium. Int. J. Oil Gas Coal Technol. 2015, 9, 215-229. [CrossRef]

88. Mastalerz, M.; Drobniak, A. Gallium and germanium in selected Indiana coals. Int. J. Coal Geol. 2012, 94, 302-313. [CrossRef]

89. Vejahati, F.; Xu, Z.; Gupta, R. Trace elements in coal: Associations with coal and minerals and their behavior during coal utilization-A review. Fuel 2010, 89, 904-911. [CrossRef]

90. Zhao, L.; Ward, C.R.; French, D.; Graham, I.T.; Simonetti, A. Major and Trace Element Geochemistry of Coals and Intra-Seam Claystones from the Songzao Coalfield, SW China. Minerals 2015, 5, 870-893. [CrossRef]

91. Dai, S.; Zhou, Y.; Zhang, M.; Wang, X.; Wang, J.; Song, X.; Jiang, Y.; Luo, Y.; Song, Z.; Yang, Z.; et al. A new type of $\mathrm{Nb}(\mathrm{Ta})-\mathrm{Zr}(\mathrm{Hf})-\mathrm{REE}-\mathrm{Ga}$ polymetallic deposit in the late Permian coal-bearing strata, eastern Yunnan, southwestern China: Possible economic significance and genetic implications. Int. J. Coal Geol. 2010, 83, 55-63. [CrossRef]

92. Zhao, C.; Duan, D.; Li, Y.; Zhang, J. Rare Earth Elements in No. 2 Coal of Huangling Mine, Huanglong Coalfield, China. Energy Explor. Exploit. 2012, 30, 803-818. [CrossRef]

93. Eskenazy, G.M. Rare earth elements and yttrium in lithotypes of Bulgarian coals. Org. Geochem. 1987,11,83-89. [CrossRef]

94. Ward, C.R.; Corcoran, J.F.; Saxby, J.D.; Read, H.W. Occurrence of phosphorus minerals in Australian coal seams. Int. J. Coal Geol. 1996, 30, 185-210. [CrossRef]

95. Swaine, D.J. Chapter 7-Variations within seams. In Trace Elements in Coal; Swaine, D.J., Ed.; Butterworth-Heinemann: London, UK, 1990; p. 278. ISBN 9780408033091.

96. Ma, J. Geochemical Characteristics of NO.6 Coal in Nanyangpo Mine. Master's Thesis, Hebei University of Engineering, Handan, China, 2018.

97. Shao, P. Paragenetic Association and Synergistic Separation of Li-Ga-REE Multielements in High-Alumina Coal and Coal Ash: A Case Study of Datong Coalfield. Ph.D. Thesis, China University of Mining and Technology, Xuzhou, China, 2019.

98. Sun, Y.; Zhao, C.; Li, Y.; Wang, J. Minimum mining grade of the selected trace elements in Chinese coal. J. China Coal Soc. 2014, 39, 744-748. 
99. Meij, R.; te Winkel, B.H. Trace elements in world steam coal and their behaviour in Dutch coal-fired power stations: A review. Int. J. Coal Geol. 2009, 77, 289-293. [CrossRef]

100. Clarke, L.B.; Sloss, L.L. IEA Coal Research. In Trace Elements: Emissions from Coal Combustion and Gasification; IEA Coal Research: London, UK, 1992; ISBN 9290292040.

(C) 2020 by the authors. Licensee MDPI, Basel, Switzerland. This article is an open access article distributed under the terms and conditions of the Creative Commons Attribution (CC BY) license (http://creativecommons.org/licenses/by/4.0/). 